Article

\title{
Land Use Dynamics of Drove Roads: The Case of Tratturo Castel di Sangro-Lucera (Molise, Italy)
}

\author{
Michele Minotti * (D), Carmen Giancola, Piera Di Marzio ${ }^{[0}$ and Paolo Di Martino \\ Department of Biosciences and Territory, University of Molise, C.da Fonte Lappone, 86090 Pesche (IS), Italy; \\ giancola@unimol.it (C.G.); piera.dimarzio@unimol.it (P.D.Marz.); dimartin@unimol.it (P.D.Mart.) \\ * Correspondence: m.minotti@unimol.it; Tel.: +39-08-7440-4111
}

Received: 23 August 2017; Accepted: 5 January 2018; Published: 8 January 2018

\begin{abstract}
Organized transhumant pastoralism has contributed to shaping the cultural landscape of many countries. It has affected areas designated for grazing, temporary and permanent shelters, and towns. Through the analysis of historical maps and recent information, in a temporal range from 1652 to 2014, this study focused on changes in land cover and conservation status of one of the main Italian transhumance paths, namely the Tratturo Castel di Sangro-Lucera. Although there are some areas where this drove road is still recognizable, it is mostly identifiable only through a few tangible signs. The methodological approach, which we present in this study, allowed us to compare historical and recent cartographies as well as archive documentation. The resulting virtual reinstatement is proposed as an efficient method for the conservation and management of material cultural heritage and can be applied in other countries with transhumance drove roads (e.g., France, Portugal).
\end{abstract}

Keywords: drove roads; transhumance; land use change; reinstatement; squatting; Molise (Italy)

\section{Introduction}

Pastoralism has been widely practiced all over the world, starting with the Neolithic period [1] and nowadays can be divided into three types: pastoral farming (pastoral mobility with little or no long-distance movement); nomadic pastoralism (pastoral mobility in highly irregular patters); and transhumant pastoralism (regular back-and-forth movements between relatively fixed locations) [2]. In the case of transhumant pastoralism, there is a broad interest in analyzing the dynamics of transhumance over time [3,4], for instance in relationship to the maintenance of particular cultural landscapes [5]. Moreover, we can say that the practice of transhumance consisted of a sustainable use of land, linked to the use of a wide number of 'ecosystem services' [6-8]. In particular, transhumance roads are considered to have played an important role as 'ecological corridors', enabling the diffusion of plant and animal species along their routes [9]. It was a role that today, because of the bad state of conservation associated with its non-use, can be defined as heavily altered.

In Europe, examples of organized transhumant pastoralism and the development of a network of routes can be found in Spain (Cañadas Reales), Italy (Tratturi), Portugal (Caminhos), France (Draylles in Languedoc), Greece (Vlachostrata), the United Kingdom (Drove roads), Germany, Romania (Drumul olior), and Bosnia and Herzegovina [10-16].

As has been widely reported, the seasonal movement of livestock allowed the use of complementary pastures, which could be located in the plains and mountains of the same mountain region (vertical transhumance between valley pastures and high-altitude pastures) or far apart and between different regions (horizontal transhumance between pastures close to or far from shepherds' homes) [17].

In European countries, transhumance can today be considered a relic, mostly because of the compromised conservation state of drove roads [18]. In fact, since 2005, the conservation of 
landscapes [19-21] and the recognition of transhumance immaterial heritage values attracted great interest, which was followed, in the case of Italy and Spain, by the nomination proposals on the UNESCO World Heritage List [22,23].

However, despite the great interest in transhumance due to the important legacy of this practice with features of intangible cultural heritages and agro-pastoral landscapes [24-29], knowledge of the conservation status of drove roads is still scant. This paucity of information, often associated with a lack of suitable study methods, may limit the identification of proper governance and the inclusion of the network of transhumance routes in a broad international context, e.g., Pan-European Ecological Corridors.

Two examples of transhumance routes' conservation state assessment are worth mentioning: Spain and Australia. In the case of Spain, since 1995, within the extensive legal framework of the "Vias Pecuarias Act" [30], drove roads in different regions have first been mapped (125,000 linear kilometers covering 421,000 hectares) and then protected by specific laws; this framework represents the first example in the world of transhumance governance [31].

In Australia a methodological approach has been used for the development of New South Wales Travelling Stock Routes using historical documents, maps, and surveying [32,33].

For many countries, information on transhumance routes' conservation status and governance is still very poor, highlighting the importance of identifying suitable methodological approaches.

\subsection{Past and Present Transhumance in Italy}

In many European countries, there was not an organized and regulated transhumance with preferential paths, as there was in Spain and in Italy. In fact, in these two countries in the 13th century, we find the first formal references to organized transhumance, to the sheep routes (tratturi in Italian) and designated organizations, to the improvement of breeding and to fiscal regulation (During the Roman era, the cattle short range displacement (alternating pastures) took place predominantly on pubblicae calles, the main traffic routes with the use of public pastures associated with them and after the payment of a fee. Only in the 4th century BC was the shepherds' privileged use of public roads formalized; this privilege was called tractoria, the term that originated the name tratturi, sing. tratturo). In the 14th century Alfonso I of Aragon relocated the efficient model of the Spanish Mesta (Honrado Concejo de la Mesta (Honorable Council of the Mesta), a private association of shepherds with royal privileges, such as the right to pass through sheep routes and municipalities' properties, and to freely graze in royal properties) in the Italian peninsula, founding the Regia Dogana della Mena delle pecore (the Royal Customhouse of transhumance), a fiscal centralized institute equipped with an efficient administrative system [34,35].

With the establishment of the Dogana, in the Tavoliere pastures transhumance was made obligatory for all flocks consisting of more than 20 sheep and was imposed even on small owners and shepherds wintering along the Abruzzo and Molise coasts or in hilly areas [36,37]. During the period of activities, the Dogana managed about 511 million sheep, with three periods of development (1445-1494, 1551-1612, and 1687-1805) separated by two periods of decline (1495-1550 and 1613-1686) [38].

This extremely complex institution was headed by a customs officer, who had the task of managing the entire institute, supported by different figures, among whom the most important were the agrimensori (Operators of Dogana offices; their main role was to verify the state of the drove roads network).

Although the drove roads were already partially traced in the 13th century, only in 1533 were the tratturi boundaries defined for the first time using milestones placed along the tratturi's outer limits and their center line [5,39]. The Dogana also defined the standard width equal as 60 Neapolitan feet (about $111 \mathrm{~m}$ ); this broadness is a unique feature of the European context. In modern times these widths were defined for the whole tratturi system: $111 \mathrm{~m}$ for the tratturi (main routes), between 32 and $38 \mathrm{~m}$ for the tratturelli (small cattle tracks) and from 12 to $18 \mathrm{~m}$ for the bracci (arms). 
Despite any kind of occupation being banned on these preferential routes for cattle, the municipalities (Universitas) and owners of the neighboring land frequently used them for multiple purposes (from cultivation to building construction) [40]. Because of these instances of abuse, it was essential to periodically check the state of preservation and, where necessary, undertake restoration. The instrument that the Dogana used to perform these checks was the Reintegra (Reinstatement): thanks to its agrimensori, the Dogana carried out new measures and investigations along the tratturi using both ancient documents and the milestones.

During the years of Dogana activity, the agrimensori carried out multiple reinstatements. The first report detailed descriptions of the state of conservation of the drove road network and about squatting or natural recolonization, but without any drawings or maps. In 1649, a reinstatement was started featuring a drove road representation, which took the name of the Doganiere Ettore Capecelatro; this ended in 1652.

In 1806, with the appointment of Joseph Bonaparte as King of Naples, the practice of the Dogana delle Pecore came to an end. In fact, on 21st May, the law of the Tavoliere delle Puglie (Apulia plains) was enacted, which put an end to the establishment of the Dogana. The reform also affected the drove road network, which became public property with the law of 1806 .

Other reinstatements containing maps were carried out in the following years; the last one was ended in 1884 by the Ispettorato Forestale di Foggia (Foggia Forestry Inspectorate) [40].

From the beginning of the 20th century, in the Tavoliere delle Puglie the pastoral economy and transhumance (already drastically reduced) were gradually replaced by cereal cultivation, which was also favored due to the sale of many state-owned and church properties $[39,41]$. Therefore, the 20th century is the period that marks transhumance as a 'relic' and represents the end of an economy based on the cyclical transfer of animals. Transhumance, by now considered only an immaterial heritage, played an important role in the formation and preservation of cultural landscapes, especially mountainous ones, not only in the territories linked closely to the drove road network but also in those that were closer or further away [39]. These secondary areas were used mostly as pastures and, where possible, were bounded by stone walls, circumscribing rural settlements, in which stone shelters for shepherds often stood.

\subsection{The Drove Roads in the Molise Region}

The southern Italian drove road network, as shown in the Carta Generale dei Tratturi, Tratturelli, Bracci and Riposi (general map of drove road network and herd resting areas) in 1912, extended itself from the Abruzzo mountains to the Capitanata plains, which includes five regions (Abruzzo, Molise, Campania, Puglia, and Basilicata), for a total length of about $2900 \mathrm{~km}$ and a total of 83 connecting elements.

In this context, Molise can be considered a geographically central transhumance region, since it played a key role by acting as a connecting element. Moreover, unlike the other regions involved in the transhumance phenomenon, Molise has the highest conservation status of the drove road network, thanks to the low population density, a location close to major city centers, and the absence of intensive agriculture.

In the last 30 years, in Molise, the drove roads have still been considered a topic of great interest. In 1997, the Parco dei Tratturi del Molise (Drove Roads Regional Park) was established [42]; in 2006, the candidacy of transhumance was proposed as a UNESCO immaterial heritage [22]; and in 2010, the Tratturi dell'Alto Molise (High Molise Drove Roads) were included in the national catalogue of historical rural landscapes [29]. Since November 2013, the main project for the enhancement of these ancient roads has been the Cammini d'Europa (European Pathway), aimed at the restoration and development of 30 historical and cultural itineraries that cross Europe (Italy, France, Ireland, Spain, Sweden, Poland, and the Czech Republic) [43]. Among the four possible paths identified, for Molise the Tratturo Castel di Sangro-Lucera was not included in this project. Nevertheless, the tratturo has 
been the subject of a promotion and enhancement project (through the identification of a public path), proposed and managed by the Attraverso il Molise association since 2013 [44] (Figure 1).

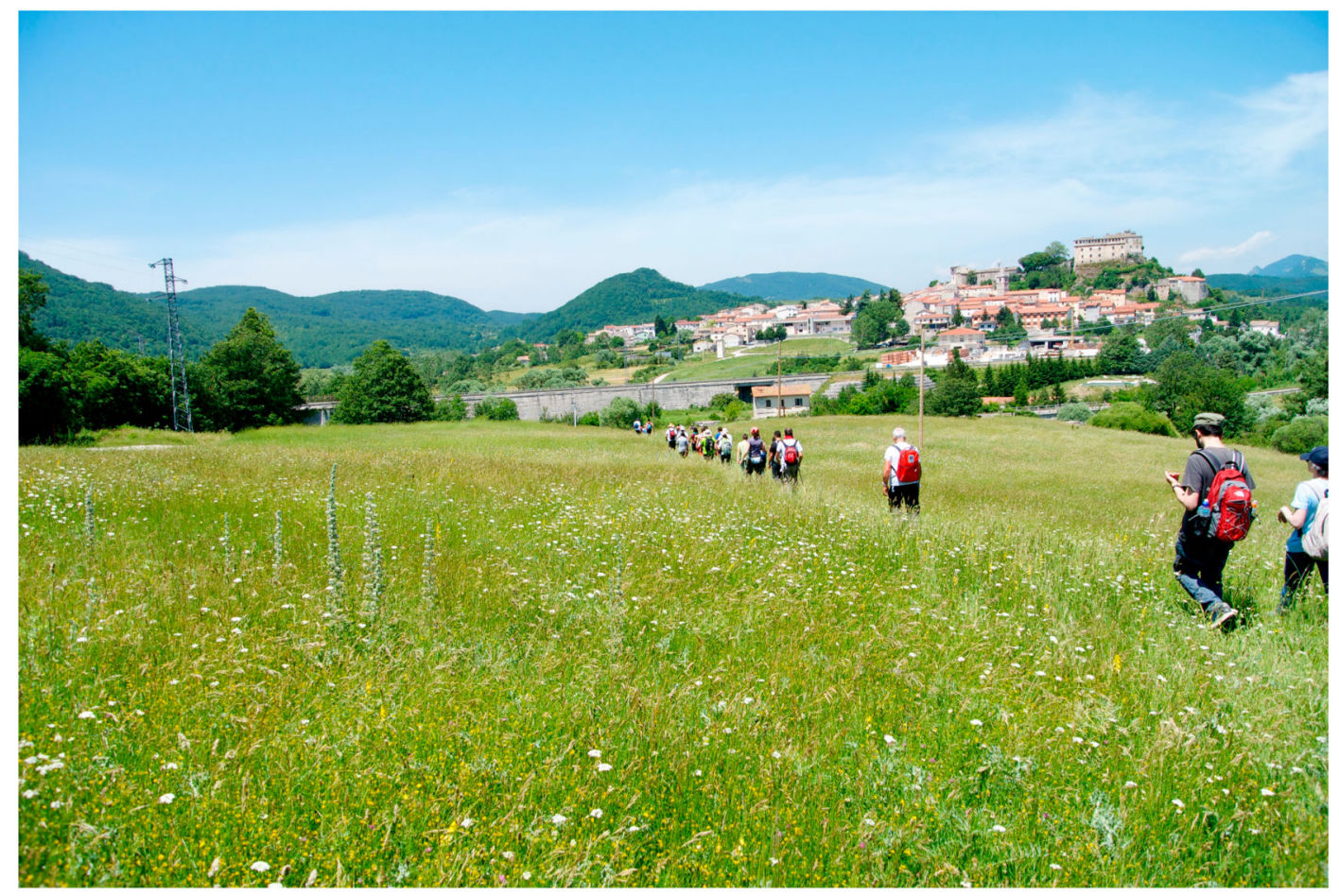

Figure 1. Trekkers along the Tratturo Castel di Sangro-Lucera.

Moreover, in 2014 a study with a less detailed scale was conducted on the conservation state of this ancient path and through the mapping of the material elements connotative of the transhumance landscape; the presence of important historical evidence was recorded in order to verify the potential use of this tratturo as a tourism resource [45].

\subsection{Research Aims}

The recognition of transhumance as an important immaterial heritage highlighted the necessity of suitable approaches for assessing its conservation status in order to better define proper tools for management and governance.

Very few methodological studies are reported in the international literature on transhumance routes' conservation state assessment. In Italy, information on transhumance routes conservation status and governance is still very poor probably because no useful and detailed methods have ever been reported.

In this context, the work reported in this paper aims to use the case study on the Tratturo Castel di Sangro-Lucera to evaluate a methodological approach that can be used to assess the conservation status of drove roads. In particular, the work objectives are to define the evolution of the drove road through its cartographic heritage and ancillary information and to provide a supportive model for planning conservation measures of an element of the cultural landscape at risk of disappearing.

\section{Materials and Methods}

\subsection{Study Area}

Molise is crossed by seven drove roads linked to one another by connecting elements, three tratturelli and two bracci [46]. The Tratturo Castel di Sangro-Lucera (Figure 2) has a linear length of 
$127.4 \mathrm{~km}$, from the locality of Vallesalice (Castel di Sangro, L'Aquila, Abruzzo) at $850 \mathrm{~m}$ a.s.l., ending up in the locality of Perazze at $117 \mathrm{~m}$ a.s.l. (Lucera, Foggia, Apulia) [47].

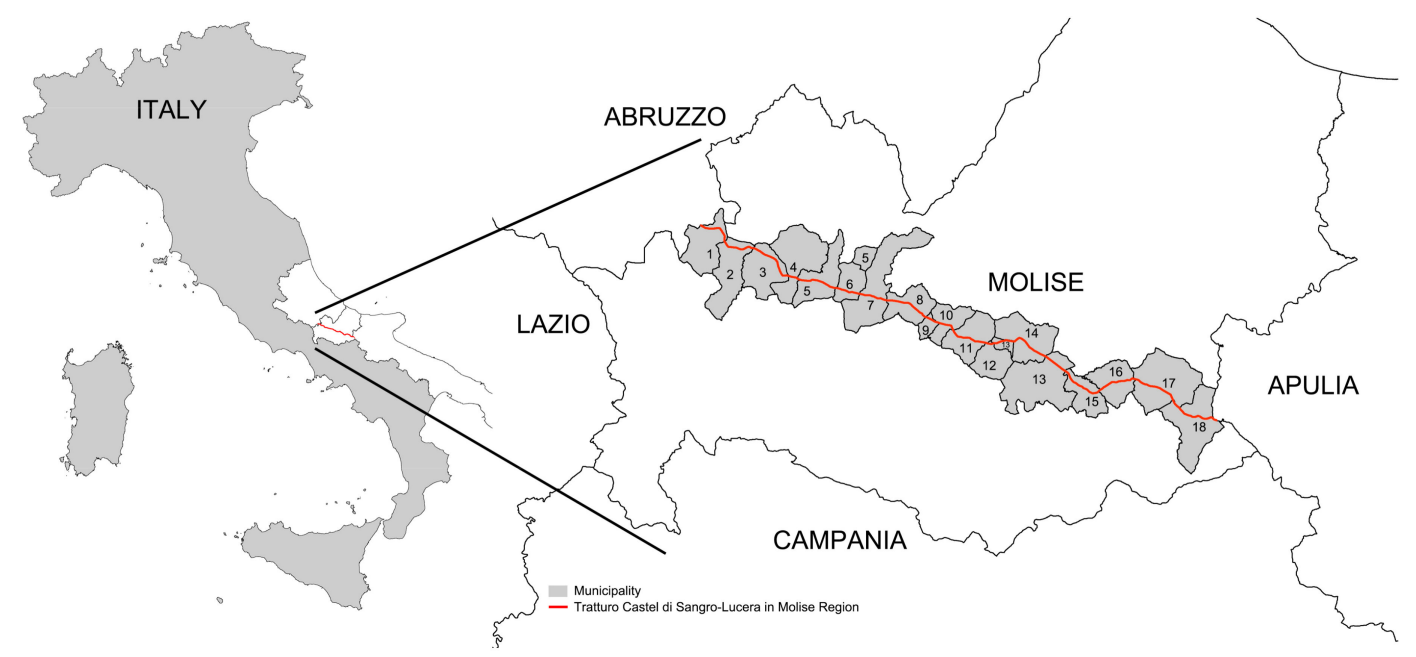

Figure 2. Tratturo Castel di Sangro-Lucera geographical extension in Molise Region. Numbering of the municipalities along the tratturo: (1) Rionero Sannitico, (2) Forlì del Sannio, (3) Roccasicura, (4) Carovilli, (5) Pescolanciano, (6) Chiauci, (7) Civitanova del Sannio, (8) Duronia, (9) Molise, (10) Torella del Sannio, (11) Castropignano, (12) Oratino, (13) Campobasso, (14) Ripalimosani, (15) Campodipietra, (16) Toro, (17) Pietracatella, (18) Gambatesa.

The Molise section of this tratturo extends for $79.12 \mathrm{~km}$ from the hamlet of Montalto (Rionero Sannitico, Isernia) to the municipality of Gambatesa (Campobasso) (Table 1), thereby excluding a section of 856 linear $\mathrm{m}(18,694 \mathrm{~m})$ that is part of Tufara municipality (Campobasso). Due to the considerable extension of the tratturo, the environmental and physical characteristics of the land surrounding the drove road are quite various. From northwest to southeast, the landscape is characterized by mountains that gradually slope to lowlands. Therefore, there are along the tratturo different vegetation communities mainly related to altitude, soils, and climatic features. From Rionero Sannitico to Pescolanciano, the vegetation is characterized by mesophilous Turkey oak (Quercus cerris L.) forests in serial contact with shrubland, dominated by blackthorn (Prunus spinosa L.) and juniper (Juniperus communis L.), and mesophilous meadows and pastures, dominated by upright brome (Bromus erectus Huds.) and tor grass (Brachypodium rupestre (Host) Roem. \& Schult). From Chiauci to Torella del Sannio, forests are dominated by white oak (Quercus pubescens Willd) and Turkey oak in serial contact with xerophilous shrublands dominated by broom (Spartium junceum L.) and xerophilous grasslands, with upright brome and fescue (Festuca circummediterranea Patzke). From Castropignano to Gambatesa, the landscape is characterized by forests dominated by deciduous broadleaves in serial contact with meagre patches of xerophilous shrublands and grasslands. In this last section of the tratturo, arable land covers the areas devoted to natural potential vegetation. 
Table 1. Brief description of the 18 municipalities crossed by the Tratturo Castel di Sangro-Lucera (listed from north to south).

\begin{tabular}{|c|c|c|c|c|c|}
\hline N. & Municipality & $\begin{array}{l}\text { Average Altitude } \\
\text { (m a.s.1.) }\end{array}$ & $\begin{array}{l}\text { Altitude Zones } \\
\text { Classification }\end{array}$ & $\begin{array}{l}\text { Tratturo Surface: } \\
\text { Hectares (\%) }\end{array}$ & $\begin{array}{l}\text { Average Altitude (m a.s.1.) } \\
\text { of the Tratturo Surface }\end{array}$ \\
\hline 1 & Rionero Sannitico & 930 & Highland & $47.06(5.70)$ & 973 \\
\hline 2 & Forlì del Sannio & 694 & Highland & $40.59(4.92)$ & 913 \\
\hline 3 & Roccasicura & 724 & Highland & $59.87(7.26)$ & 873 \\
\hline 4 & Carovilli & 923 & Highland & $16.16(1.96)$ & 874 \\
\hline 5 & Pescolanciano & 901 & Highland & $53.85(6.53)$ & 823 \\
\hline 6 & Chiauci & 830 & Highland & $36.94(4.48)$ & 761 \\
\hline 7 & Civitanova del Sannio & 743 & Highland & $33.27(4.03)$ & 633 \\
\hline 8 & Duronia & 697 & Highland & $61.46(7.45)$ & 772 \\
\hline 9 & Molise & 754 & Highland & $18.26(2.21)$ & 770 \\
\hline 10 & Torella del Sannio & 679 & Hill & $28.05(3.40)$ & 800 \\
\hline 11 & Castropignano & 533 & Hill & $52.39(6.35)$ & 570 \\
\hline 12 & Oratino & 597 & Hill & $9.67(1.17)$ & 492 \\
\hline 13 & Campobasso & 657 & Highland & $64.02(7.76)$ & 663 \\
\hline 14 & Ripalimosani & 619 & Highland & $56.69(6.87)$ & 722 \\
\hline 15 & Campodipietra & 498 & Hill & $60.35(7.32)$ & 563 \\
\hline 16 & Toro & 459 & Hill & $53.49(6.48)$ & 345 \\
\hline 17 & Pietracatella & 446 & Lowland & $61.74(7.48)$ & 273 \\
\hline 18 & Gambatesa & 414 & Lowland & $71.11(8.62)$ & 213 \\
\hline \multicolumn{4}{|c|}{ Total area of the tratturo surface } & $825(100)$ & \\
\hline
\end{tabular}

\subsection{Materials}

The definition of the limits and description of the land cover changes that involved Tratturo Castel di Sangro-Lucera were obtained through comparative analysis of (see Table 2):

- 4 historical maps: Capecelatro's Atlas maps (1651), Map of southern Italy (1875), Bonamici's reinstatement maps (1875-1884), The Map of Italy (1957),

- maps of land and property: the Land Registry maps (1947-2005 and 2016),

- 2 land cover maps derived using photointerpration of aerial photograms of the GAI flight (1954), and photointerpration of ESRI aerial images (2014),

- 3 archival sources: Capecelatro's Atlas, Bonamici's reinstatement, Italian Land Registry.

More details on these sources are given in Appendix A.

Table 2. List of the maps used in this study.

\begin{tabular}{cccccc}
\hline & Time Frame & Scale & Source & Format & Used for \\
\hline $\begin{array}{c}\text { Capecelatro's } \\
\text { Atlas }\end{array}$ & 1651 & - & $\begin{array}{c}\text { Archivio di Stato di Foggia } \\
\text { (State Archive of Foggia) }\end{array}$ & *.jpg & $\begin{array}{c}\text { Analysis of land } \\
\text { cover changes }\end{array}$ \\
\hline $\begin{array}{c}\text { Map of } \\
\text { southern Italy }\end{array}$ & 1875 & $1: 50,000$ & ITMI & paper & $\begin{array}{c}\text { Reconstruction of } \\
\text { tratturo's limits }\end{array}$ \\
\hline $\begin{array}{c}\text { Bonamici's } \\
\text { reinstatement }\end{array}$ & $1875-1884$ & $\begin{array}{c}1: 1000 \\
1: 2000\end{array}$ & $\begin{array}{c}\text { Archivio di Stato di } \\
\text { Campobasso (State } \\
\text { Archive of Campobasso) }\end{array}$ & *.tif & $\begin{array}{c}\text { Reconstruction of } \\
\text { tratturo's limits } \\
\text { Analysis of land } \\
\text { cover changes }\end{array}$ \\
\hline $\begin{array}{c}\text { The Map of } \\
\text { Italy }\end{array}$ & 1957 & $1: 25,000$ & IGMI & $*$.ecw & $\begin{array}{c}\text { Reconstruction of } \\
\text { tratturo's limits }\end{array}$ \\
\hline $\begin{array}{c}\text { The Land } \\
\text { Registry }\end{array}$ & $1947-2005$ & $1: 2000$ & $\begin{array}{c}\text { Land Registry Office and } \\
\text { Molise Region Portale } \\
\text { Cartografico }\end{array}$ & $\begin{array}{c}\text { Paper and } \\
\text { wms link }\end{array}$ & $\begin{array}{c}\text { Reconstruction of } \\
\text { tratturo's limits }\end{array}$ \\
\hline $\begin{array}{c}\text { Land cover } \\
\text { map 1954 }\end{array}$ & $1954-1957$ & $1: 10,000$ & Our original data & $*$.shp & $\begin{array}{c}\text { Analysis of land } \\
\text { cover changes }\end{array}$ \\
\hline $\begin{array}{c}\text { Land cover } \\
\text { map 2014 }\end{array}$ & 2014 & $1: 10,000$ & Our original data & $*$ *shp & $\begin{array}{c}\text { Analysis of land } \\
\text { cover changes }\end{array}$ \\
\hline
\end{tabular}




\subsection{The Reconstruction of the Tratturo's Limits}

The quadrants with a scale of 1:50,000, drawn in 1875, were digitized and georeferenced using the ARCMAP 10.1-ESRI program. To georeference the quadrants, IGM tablets were used, since they were already georeferenced (Datum WGS 84/33 Nord). Although the quadrants, with a scale of 1:50,000, were produced with less detail than the tablets (a scale of 1:25,000), it was possible to retrace the boundaries of the Tratturo Castel di Sangro-Lucera with constant continuity. Although the tablets report a detailed toponymy, they do not often draw the tratturo. This is due to the use of aerial photography: it was not always possible to individuate the tratturo because of its conservation state damaged by woodland, forestry recolonization or squatting, or because it was difficult to individuate it, for example, near rivers or towns.

After the preliminary recognition of the limits on a scale of 1:50,000, using the sheets, we again outlined the Tratturo Castel di Sangro-Lucera's boundaries on a scale of 1:25,000; but to trace the real boundaries of the tratturo we used the information collected in the Land Registry, referring to maps (updated in 2005) reporting all the land parcels, and to cadastral certificates (updated in 2016), which report details about the property of land parcels. The land parcels were examined using the WMS service and displayed through ARCGIS software. This allowed us to retrace the tratturo's limits on a scale of 1:2000, since in a lot of sections there was a positive comparison with the limits drawn in the tablets; moreover, to validate this elaboration phase and retrace the limits of those portions of the tratturo that did not coincide with what was reported in the tablets, we used the information from cadastral certificates. We acquired this documentation from the Agenzia del Territorio (Territory Agency), which provided us with information on public property related to the tratturo and information about land parcels near the tratturo, whose annexation was not definite. Even in this case, the only exceptions, during the redrawing of the tratturo, concerned those situations where the tratturo crosses towns or is near rivers.

Through the georeferentiation in the GIS setting, the maps of Bonamici's reinstatement were overlaid to the limits of the tratturo traced using the cadastre information (Figure 3).

This elaboration phase was carried out with particular attention in order that the measurements between milestones and the width of the Tratturo Castel di Sangro-Lucera identified on the map would reflect the real ones; therefore, it was possible to obtain accurate measurements with an average error of $8 \mathrm{~m}$.

Surveys along the tratturo were carried out to geolocalize the tangible traces; the geolocalization of all the tangible elements were performed using a professional GPS (Trimble GeoXT_Figure 4). During these surveys 20 milestones were individuated (Table 3) and the information about the geolocalization were used to validate the maps' georeferencing. 


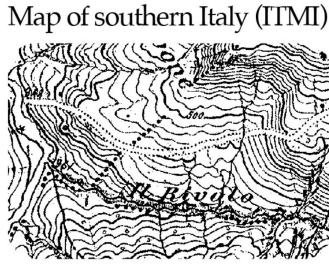

Map of Italy (IGMI)

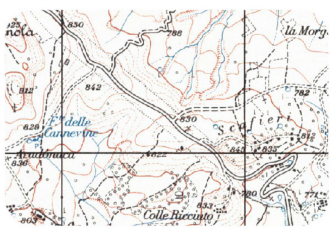

Land Registry information
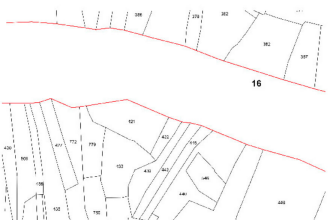

Eduardo Bonamici's reinstatement

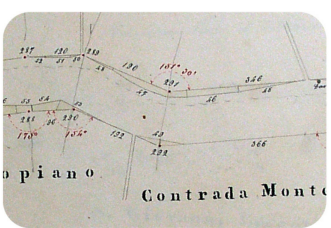

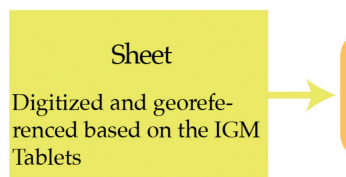

Drove road continuos limits 1:50000

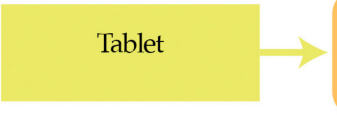

Drove road limits 1:25000

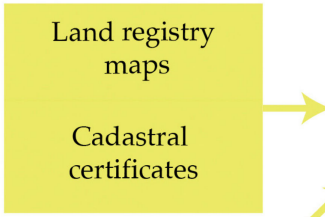

Drove road real limits to 2014 1:2000

Figure 3. Schematic representation of the methodology used.

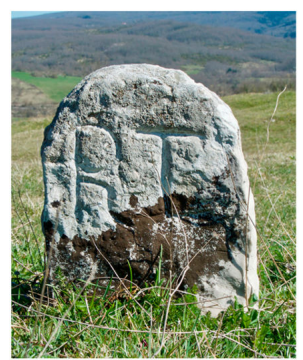

(a)

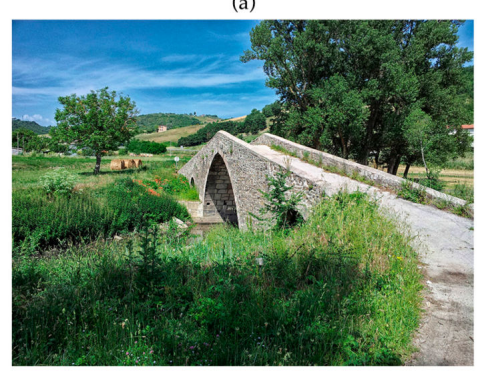

(c)

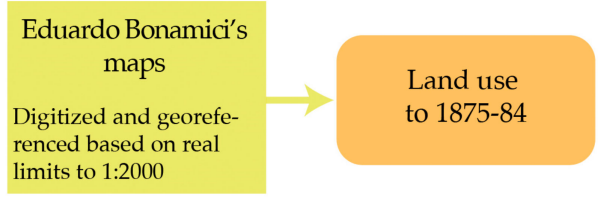


Table 3. Number of milestones present in the 18 municipalities, arranged from $\mathrm{N}$ to $\mathrm{S}$, drawn in Capecelatro's Atlas (CA) and in Bonamici's reinstatement (BR), and those recorded during the field surveys (S).

\begin{tabular}{lccc}
\hline Municipality (Toponyms mentioned in the Capecelatro's Atlas) & CA & BR & S \\
\hline Rionero Sannitico (loc. Feudo di Monte Alto) & 18 & 17 & 1 \\
Forlì del Sannio (loc. Feudo dello Falascuso) & 26 & 24 & 2 \\
Roccasicura (Rocca Cicuna) & 22 & 34 & 5 \\
Carovilli (Carovilli) & 11 & 8 & 0 \\
Pescolanciano (Pesco Lanciano) & 30 & 31 & 6 \\
Chiauci (Chiauci) & 17 & 20 & 1 \\
Civitanova del Sannio (Civita Nova) & 23 & 24 & 2 \\
Duronia (Civita Vecchia) & 29 & 24 & 0 \\
Molise (Molise) & 14 & 14 & 0 \\
Torella del Sannio (Torella) & 15 & 11 & 0 \\
Castropignano (Castro Pignano) & 24 & 35 & 0 \\
Oratino (Ratino) & 6 & 4 & 0 \\
Campobasso (loc. S. Stefano) & 15 & 16 & 0 \\
Ripalimosani (Territorio della Ripa) & 21 & 19 & 1 \\
Campobasso (loc. Campo Senarcuni) & 12 & 8 & 1 \\
Campodipietra (Campo di Pietra) & 30 & 48 & 1 \\
Toro (Tuoro) & 27 & 30 & 0 \\
Pietracatella (Predicatiello) & 10 & 19 & 0 \\
Gambatesa (Gammatesa) & 9 & 33 & 0 \\
\hline & 359 & $\mathbf{4 1 9}$ & $\mathbf{2 0}$ \\
\hline
\end{tabular}

\subsection{The Overlay between the Two Reinstatements}

The overlay of Bonamici's reinstatement maps with the limits reported in the Land Registry maps effectively matched, except for a few cases; so, this elaboration allowed us to redraw the tratturo's limits, especially in those instances where the Land Registry maps do not report them, that is near rivers and across towns. To match the maps of the two reinstatements (those of Bonamici and Capecelatro), a long-lasting comparison was carried out, using the toponymy (Considering both the linguistic differences of Italian used from 1649 to 1957 and the changes of some places' names, see Table 3 concerning the municipalities' names), the description of Capecelatro's Atlas, and the distance between milestones (Table 4).

These distances were calculated through a complex procedure, using the information related to all milestones recorded on a spreadsheet. In accordance with Bonamici's reinstatement maps, the milestones were organized in two columns: the odd ones were listed in one column, identifying the north side of the tratturo, and the even ones in the other column, identifying the south side. Moreover, the distances between every couple of odd and even milestones were reported in the two consecutive columns. It was useful to associate with every milestone the municipality where they are situated. On the same spreadsheet, with the same structure we reported the information specified in Capecelatro's Atlas: milestones, divided into odd and even, and the distances in Neapolitan feet between every couple of odd and even milestones. With this system, it was possible to identify the milestones belonging to the two different map typologies, with comparable distances. 
Table 4. Inter-milestones distances in meters (Dist.), proceeding from $\mathrm{N}$ to $\mathrm{S}$ along the Tratturo Castel di Sangro-Lucera, in the Capecelatro's Atlas and the Bonamici's reinstatement. The table reports also the milestone numbers (MN), the number of milestones comprises in the interval (NM), the Capecelatro's Atlas sheet, the Bonamici's reinstatement table, and the difference (in meters) between the distances calculated on the two data sets.

\begin{tabular}{cccccccccc}
\hline & \multicolumn{7}{c}{ Capecelatro's Atlas } & \multicolumn{7}{c}{ Bonamici's Reinstatement } \\
\cline { 2 - 9 } Municipality & MN & Dist. & NM & Sheet CA & MN & Dist. & NM & Table BR & Difference \\
\hline Rionero & $08-10$ & 632.4 & 2 & 282 & $20-22$ & 630 & 2 & LXXXXI & 2.4 \\
Sannitico & & & & & & & & & \\
Forli del & $18-20$ & 651.0 & 2 & 282 & $34-36$ & 660 & 2 & LXXVI & -9 \\
Sannio & & & & & & & \\
Roccasicura & $36-38$ & 241.8 & 2 & 281 & $56-58$ & 242 & 2 & LXXI & -0.2 \\
Roccasicura & $44-46$ & 706.8 & 2 & 281 & $67-69$ & 705 & 2 & LXVIII & 1.8 \\
Pescolanciano & $60-62$ & 697.5 & 2 & 280 & $91-93$ & 700 & 2 & LXIV & -2.5 \\
Chiauci & $82-84$ & 520.8 & 2 & 279 & $116-118518$ & 2 & LIV & 2.8 \\
Chiauci & $86-88$ & 483.6 & 2 & 279 & $122-124482$ & 2 & LIII & 1.6 \\
Civitanova & $92-94$ & 362.7 & 2 & 279 & $130-132360$ & 2 & XLVII & 2.7 \\
Civitanova & $99-101$ & 511.5 & 2 & 283 & $143-145518$ & 2 & XLII & -6.5 \\
Molise & $129-131$ & 316.2 & 2 & 284 & $173-175315$ & 2 & XXXIV & 1.2 \\
Castropignano & $147-149$ & 372.0 & 2 & 285 & $197-199378$ & 2 & XXIX & -6 \\
Castropignano & $155-157$ & 223.2 & 2 & 285 & $210-212207$ & 2 & XXVII & 16.2 \\
Ripalimosani & $173-175$ & 725.4 & 2 & 286 & $236-238630$ & 2 & XXII & 95.4 \\
Campodipietra & $199-201$ & 465.0 & 2 & 287 & $267-269462$ & 2 & XV & 3 \\
Campodipietra & $209-211$ & 465.0 & 2 & 287 & $286-292456$ & 4 & XIII & 9 \\
Toro & $231-233$ & 595.2 & 2 & 301 & $327-331592$ & 3 & X. IX & 3.2 \\
Gambatesa & $251-253$ & 1860.0 & 2 & 302 & $371-3831871$ & 7 & II. I & -11 \\
Gambatesa & $253-255$ & 706.8 & 2 & 303 & $383-385716$ & 2 & I & -9.2 \\
\hline
\end{tabular}

\subsection{Land Cover Maps of 1954 and 2014}

The land cover maps of 1954 and 2014 were produced within the limits of the tratturo previously reconstructed. To produce a land use map for 1954, the relative frames were scanned and then georeferenced using ARCMAP 10.1. We considered three land use classes following the main CORINE land cover classification [48]: artificial surfaces (urban fabric, road rail networks, etc.), agricultural areas (arable land, permanent crops, etc.), and forest and semi-natural areas (forests, grasslands, shrubland, etc.). Accuracy assessment was carried out on the land-use map of 2014, with a number of validation points of 195, to have an accuracy of $85 \%$ [49]. Validation points were randomly distributed within the drove road's boundaries in ARCMAP 10.1 using Arc Toolbox "Create Random Points"; then they were checked in field with a professional GPS. Overall accuracy and kappa coefficient [50] were used for assessing the performance.

\section{Results}

\subsection{The Dynamics of Squatting on the Tratturo Castel Di Sangro-Lucera}

During the period of Capecelatro's Atlas, the tratturo performed in full its role as a path for herds through the Molise Region over 42.415 Neapolitan feet, equal to $78.9 \mathrm{~km}$. Through careful reading of the description reported in the reinstatement and analysis of maps, it can be gathered that the width of 60 Neapolitan feet between the milestones positioned on one side of the tratturo and the milestones situated on the opposite side represented the standard across the tratturo. Indeed, where this distance did not coincide with the fixed standard, the Agrimensore restored it, adding new milestones or repositioning those that had been moved on purpose. On Capecelatro's maps, exceptional attention was given to reporting on the milestones positioned along the center line, which are continuously reported from Montalto to Toro. It is plain to see that the maps represent the best pathway in the proximity of milestones positioned along the center line. It can be a rendering of an 
'ideal path' rather than the real presence of a preferential path network; but on one map (Sheet $282 \mathrm{AC}$ ) near the Vandra stream in Forli del Sannio, this path network is not reported, probably because there was not a preferential path. The state of conservation of the tratturo is mostly excellent, with sporadic reports referring to the presence of buildings or shrubland and forests. In particular, considering the section of tratturo included in the Molise Region, we check only 20 squatting related to buildings that were designated as houses, taverns, or churches; among these, only nine were reported in the previous reinstatement of Fabrizio Di Sangro (1574) and for them the practice of eque comodo was granted [51]. This practice offered the opportunity to private citizens to use the state property of the tratturo in exchange for their own equivalent property; however, the benefits would be removed. Squatting on the tratturo's land as agricultural surfaces or fencing is rarely reported. Other information, which attests to the excellent state of conservation along the tratturo, is deducible from only three descriptions regarding the presence of shrubland and/or forests near Vallone San Pietro in Pescolanciano (Sheet 280 AC), Colle dei Cerri in Roccasicura (Sheet 281 AC) and Defenza della Covatta (Sheet 285 AC) in the village of Santo Stefano (CB). In these cases, the toponymy of Capecelatro's Atlas relates to that reported in IGM tablets.

The maps of Bonamici's reinstatement, carefully drawn using the graphic and numerical method, were a faithful representation of reality on a very detailed scale. The length of the tratturo in the Molise Region reported in these maps is $78.8 \mathrm{~km}$ with an extension of 871 hectares; so the length differs by only $0.100 \mathrm{~km}$ from the data reported in Capecelatro's Atlas. On examining the maps, two important characteristics can be noted: one refers to the confirmation of the width of the tratturo, which is $111 \mathrm{~m}$, as reported in Capecelatro's Atlas; the second refers to the absence of the preferential path along the tratturo, probably because mapping the path would have required a great effort, but at the same time it would be worthless because of the variability of the paths. Also, to realize this reinstatement, close attention was paid to drawing the boundaries of the tratturo, verifying the exact distance between the milestones positioned on the two boundaries, adding new milestones where they were missing and in cases where there were squattings of large extension. As a result of the comparison between the information included in the two reinstatements, it is clear that during the period between 1653 and 1883 there was widespread trespassing along the tratturo. Although the restoration accomplished through other reinstatements occurred between the Capecelatro's Atlas and Bonamici's reinstatement, which could be followed by the drawing up reports and relative money sanctions, squatting was a common practice. The proof of this conduct is the 440 squatting reports related to facilities assigned to houses, taverns, and churches, which were mainly situated near towns. Among those squatting, only 41 were reported in a previous reinstatement and only for 16 was the eque comodo agreed. Generally, the most conspicuous class of squatting was represented by agricultural areas, mainly arable land, with 1733 squatting, among which only three were authorized. It was clear that, even if the tratturo still performed the role of a herd path, it began to be used as land suitable for agriculture. During this period, the plant recolonization and thus the vegetation succession on the tratturo were more evident, as described in four reports from Bonamici's reinstatement, although they do not coincide with Capecelatro's Atlas information. The first three reports describe the mountainous area on the border with the Abruzzo Region through which the tratturo passes: first in Forlì del Sannio (Tables LXXVII and LXXVIII BR) near the locality of Falascoso (toponyms extracted from IGM 1957 maps), where the forest widely recolonized the tratturo; second in Roccasicura (Table LXX BR) near the locality of Fonte Pagano and in Pescolanciano (Table LXV RB) near the locality of Vallone San Pietro, where the woody vegetation partly recolonized the tratturo (Figure 5). This latter report corresponds to the one already reported in Capecelatro's Atlas. The third one is reported for Toro (Table IX BR), near the confluence between the Fiumarello torrent and the Tappino torrent.

By analyzing the maps of Bonamici's reinstatement, which report in detail the type of squatting on the tratturo and the land use layers referring to 1954 and 2014 (Overall accuracy $=93 \%$, K coefficient $=0.91$ ), it was possible to carry out a diachronic analysis of land use changes in the last 133 years (Figure 6). The information related to squatting was subdivided into three classes: the artificial class, which includes 
the settlements pattern, the agricultural class, which includes all arable land and permanent crops, and natural vegetation recolonization (forests and shrublands). Everything else that is not classified in these three categories is grouped as grassland and pastures, which represent the unaltered state of the tratturo.

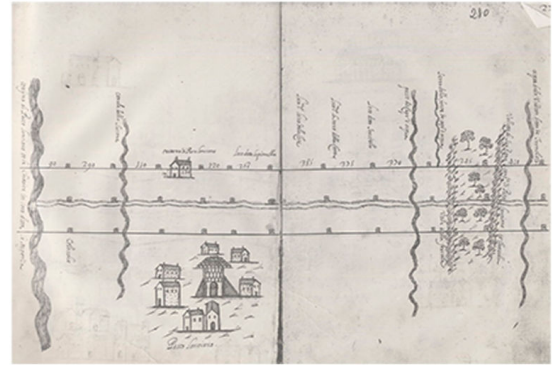

(a)

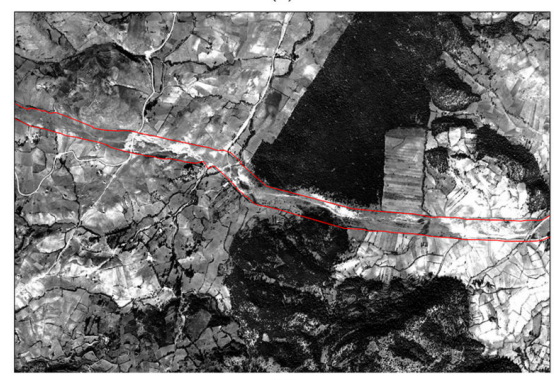

(c)

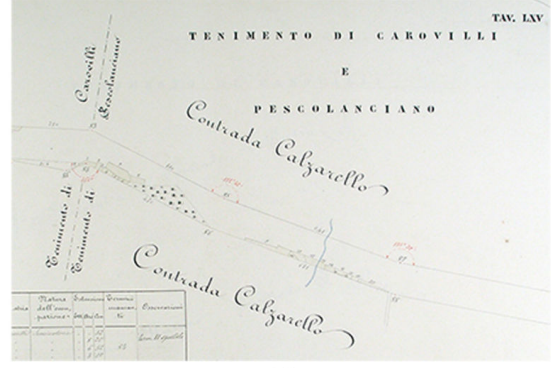

(b)

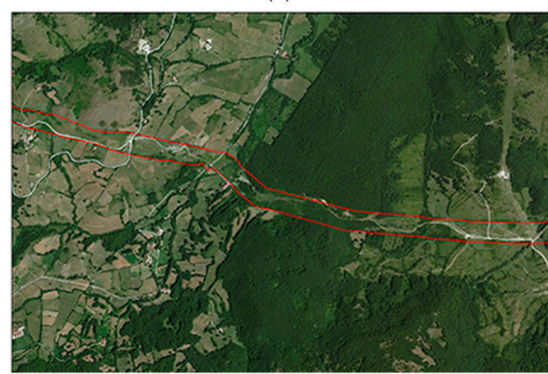

(d)

Figure 5. Comparison of the Tratturo Castel di Sangro-Lucera near the Vallone San Pietro (Municipalities of Carovilli and Pescolanciano-IS) among: (a) the Capecelatro's Atlas Sheet 280 (Authorization to publish n. 5/2016, prot. 2915/28.34.01.10 del 14.10.2016 granted by the Director of Archivio di Stato di Foggia); (b) the Bonamici's reinstatement table LXV (Authorization to publish n. 0004086/28.28.00/1 del 20.09.2016 granted by the Director of Archivio di Stato di Campobasso); (c) the orthophoto of 1954; (d) the aerial image of 2014.

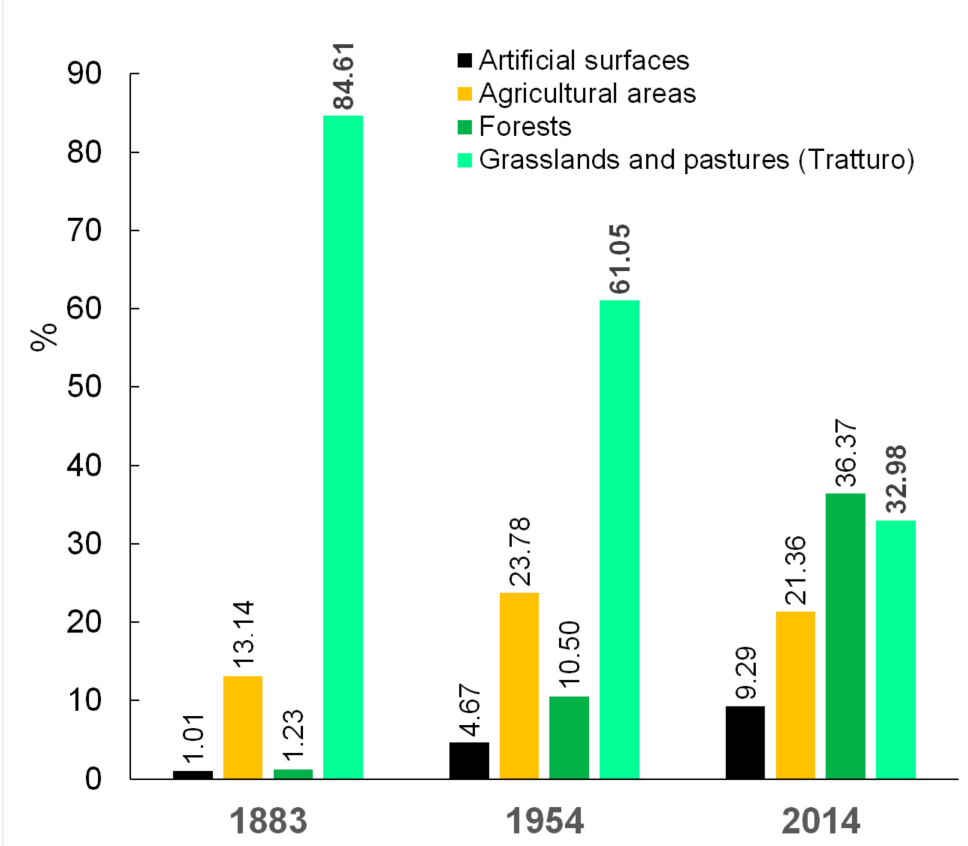

Figure 6. Percentage of land use squatting classes concerning the entire tratturo in the Bonamici's reinstatement (1883) and in the maps made for 1954 and 2014. 
Moreover, through the analysis of maps and information contained in Bonamici's reinstatement, it is evident that the tratturo extended for 870.92 hectares, of which 134.01 hectares $(15.39 \%)$ were affected by occurrences of squatting with a width often bigger than $111 \mathrm{~m}$. In particular, 8.82 hectares were occupied by the urban pattern; this condition was mainly observed where the tratturo passed nearby towns, which, over time, took in these squatting buildings. Moreover, 114.45 hectares were affected by squatting included in the agricultural class, distributed along the tratturo, but often in piedmont areas. Only 10.73 hectares were affected by vegetation dynamics, which were gathered in mountainous areas coinciding with where the tratturo passed through forests.

The land use maps of the Tratturo Castel di Sangro-Lucera concerning 1954 and 2014 reveal a total surface of 825 hectares, less than the measurements reported in Bonamici's reinstatement; the cause is the different identification of the tratturo's boundaries that we discussed at length before.

Analyzing the information from the maps of 1954, the tratturo was in a state of abandonment because it was characterized by squatting for 328.55 hectares (38.95\%). The urban pattern was widespread over 45.71 hectares, and it was mainly represented by the enlargement of towns along the tratturo. The agricultural class covered 196.22 hectares and was predominant in plains, while natural vegetation recolonization was characteristic of mountainous areas over a total of 86.62 hectares.

Recently (referring to the land use map of 2014), the tratturo has changed drastically. In fact, 552.89 out of 825 hectares $(67.02 \%)$ are affected by squatting and natural vegetation recolonization. In particular, the woody vegetation evenly developed along the tratturo for 300.08 hectares, with the exception of Campodipietra and Campobasso municipalities. The urban pattern increased mainly near towns, and occasionally away from them, over a total of 76.61 hectares, whereas the agricultural lands decreased with a surface of 176.20 hectares compared with 1954.

Comparison at the municipality level of the squatting dynamics among the land use maps referring to the three historical periods (Table 5) illustrates that in three municipalities there is a prevalent squatting dynamic (Forlì del Sannio, Ripalimosani, and Castropignano).

Table 5. Comparison, by municipality, of employment patterns, in hectares, among the Bonamici's reinstatement (1883) and the maps made for 1954 and 2014. As: Artificial surfaces; Aa: Agricultural areas; Fsa: Forest and semi natural areas; Dr: Tratturo (drove road) in its preserved state (grassland).

\begin{tabular}{ccccccccccc}
\hline & \multicolumn{3}{c}{$\mathbf{1 8 8 3}$} & & & $\mathbf{1 9 5 4}$ & \multicolumn{5}{c}{$\mathbf{2 0 1 4}$} \\
\cline { 2 - 10 } Municipality & As & Aa & Fsa & As & Aa & Fsa & As & Aa & Fsa & Dr \\
\hline Rionero Sannitico & 0.13 & 2.63 & 0 & 2.95 & 4.98 & 6.44 & 5.75 & 2.82 & 26.74 & 11.75 \\
Forlì del Sannio & 0.03 & 2.41 & 6.20 & 1.69 & 3.64 & 33.82 & 1.46 & 0.20 & 36.38 & 2.55 \\
Roccasicura & 0.04 & 12.32 & 1.40 & 0.36 & 2.18 & 3.35 & 3.22 & 1.22 & 27.50 & 27.93 \\
Carovilli & 0 & 1.08 & 0 & 0.16 & 0.27 & 0.09 & 0.97 & 0.44 & 4.85 & 9.90 \\
Pescolanciano & 2.88 & 6.81 & 2.48 & 6.81 & 0.74 & 2.01 & 9.23 & 0.03 & 22.06 & 22.52 \\
Chiauci & 0.12 & 5.60 & 0.04 & 0.69 & 1.25 & 2.75 & 2.56 & 0.00 & 21.83 & 12.55 \\
Civitanova & 2.68 & 18.98 & 0 & 3.74 & 2.03 & 0.25 & 5.03 & 2.66 & 17.24 & 8.34 \\
Duronia & 0.06 & 11.84 & 0 & 5.70 & 8.82 & 1.18 & 6.90 & 1.43 & 24.73 & 28.40 \\
Molise & 0.99 & 1.18 & 0 & 1.22 & 2.00 & 0.00 & 1.88 & 1.83 & 5.25 & 9.31 \\
Torella del Sannio & 1.07 & 1.26 & 0 & 1.11 & 1.66 & 0.01 & 3.92 & 6.98 & 2.03 & 15.12 \\
Castropignano & 0.74 & 3.62 & 0.02 & 3.82 & 9.16 & 9.46 & 5.27 & 15.00 & 19.84 & 12.28 \\
Oratino & 0 & 0.10 & 0 & 0.42 & 2.01 & 6.22 & 0.38 & 1.99 & 1.91 & 5.40 \\
Campobasso & 0 & 8.41 & 0 & 6.85 & 24.42 & 3.86 & 8.04 & 30.38 & 5.05 & 20.56 \\
Ripalimosani & 0 & 4.98 & 0 & 3.98 & 32.85 & 2.05 & 4.24 & 38.42 & 3.89 & 10.14 \\
Campodipietra & 0.08 & 6.11 & 0 & 3.55 & 35.43 & 2.49 & 8.30 & 29.45 & 3.89 & 18.72 \\
Toro & 0 & 12.98 & 0.59 & 1.93 & 12.47 & 5.77 & 3.37 & 15.13 & 21.03 & 13.96 \\
Pietracatella & 0 & 10.95 & 0.01 & 0.49 & 28.67 & 3.17 & 2.15 & 14.26 & 28.26 & 17.07 \\
Gambatesa & 0.01 & 3.20 & 0 & 0.24 & 23.63 & 3.71 & 3.94 & 13.96 & 27.60 & 25.62 \\
\hline
\end{tabular}

In Pescolanciano (Figure 7), the artificial areas reached high values in two periods out of three; in 2014 settlement patterns developed over 9.23 hectares, which represents $17.14 \%$ of the entire surface of 
the tratturo that is included in the municipality. Given the fact that Pescolanciano has built up around the tratturo, there was a need to expand the road and path network. With regard to agricultural areas, this class increased over time, especially in Ripalimosani, a flat countryside suitable for cultivations and characterized by plains; in 2014 the surface area committed to agricultural activities on tratturo property was $67.76 \%$ of the entire municipality territory covered by the tratturo.

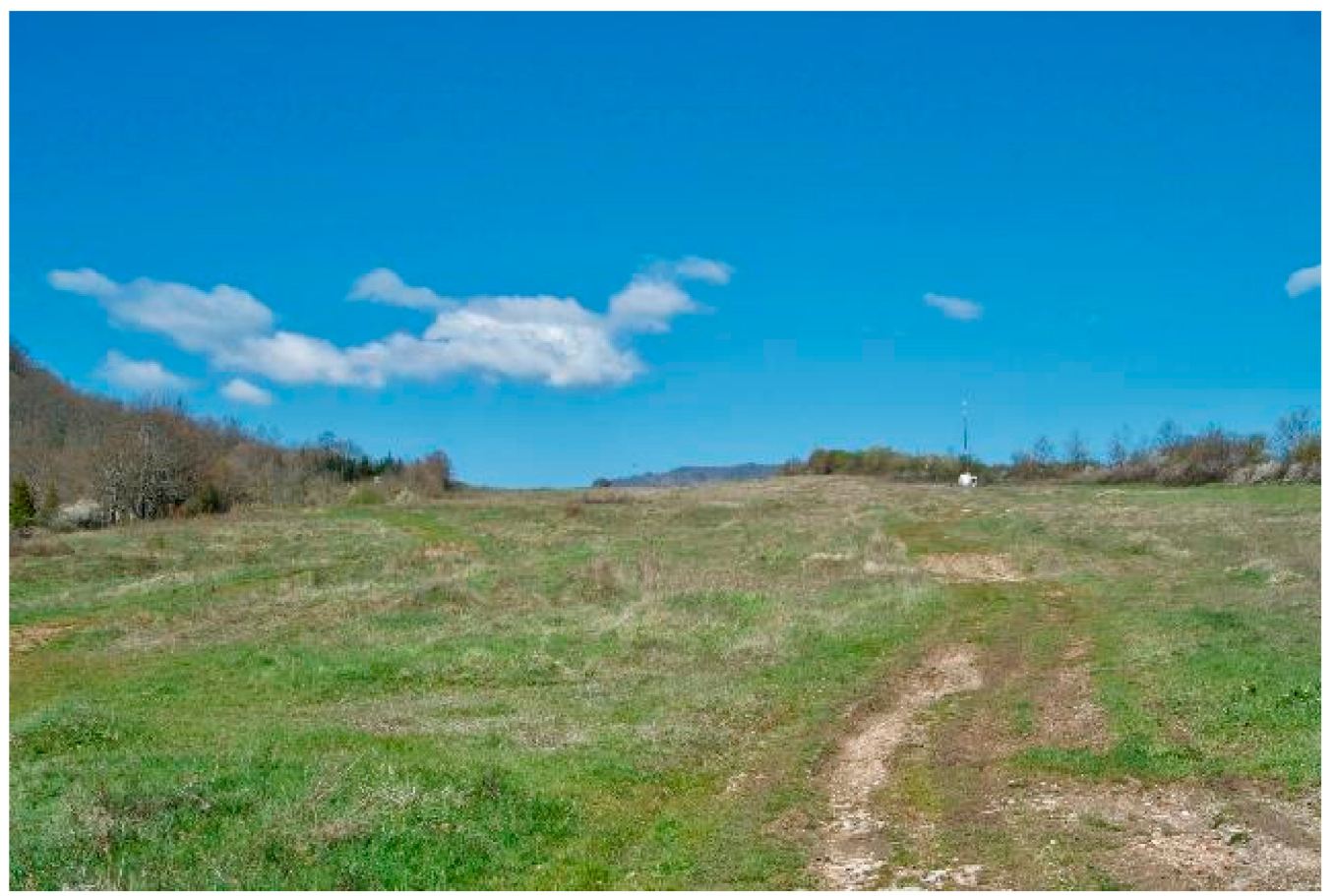

Figure 7. Tratturo image in the municipality of Pescolanciano (IS). Capecelatro's Atlas Sheet 280, Bonamici's reinstatement Table LXIII, Tablet IGM 153 II-SE.

Natural vegetation recolonization is the dynamic that distinguishes the mountainous areas, as a result of the abandonment of agriculture and livestock practices, typical customs of this bioclimatic zone. In Forlì del Sannio we recorded the highest values for the three periods; in 2014, 89.63\% of the entire municipality surface area included in the tratturo was invaded by woody vegetation. In particular, mesophilous Turkey oak woods mainly reforested the highland zones; meanwhile, xerophilous deciduous broadleaved forests, with maples (Acer campestre L., A. monspessulanum L.), manna ash (Fraxinus ornus L.), and European hop-hornbeam (Ostrya carpinifolia Scop.) recolonized the tratturo in hill areas.

\subsection{The Conservation Hot Spot}

In Table 6, seven municipalities are listed (Duronia, Roccasicura, Gambatesa, Pescolanciano, Campobasso, Campodipietra, and Pietracatella) that in 2014 presented intact surface areas of the tratturo, that is, surface areas characterized by grasslands larger than 17 hectares for each town.

Given that every one of these municipalities is characterized by $7 \%$ of the tratturo Castel di Sangro-Lucera surface area (see Table 1), we can regard them as the most suitable for the conservation and promotion of the tratturo. These municipalities are homogenously distributed along the tratturo, from mountainous areas neighboring Abruzzi through the hilly central part of Molise over to the plain bordering Puglia. The difficulties regarding the conservation of tratturo Castel di Sangro-Lucera are different, depending on the zones being considered. In mountainous areas it is necessary to mitigate the natural recolonization of woody vegetation, while in hilly areas it is essential to restrict the cultivation of grasses in favor of perennial forage and promote agricultural practices such as mowing to 
preserve the tratturo in its intact state. Furthermore, on the plain bordering Puglia, where both of these problems occur, the actions would aim to control the vegetation and protect traditional agriculture.

Table 6. Land use squatting classes in percentage updated to 2014; the data refer to municipalities interested by presence of hot spots.

\begin{tabular}{ccccc}
\hline & Artificial Surfaces (\%) & Agricultural Areas (\%) & Forests (\%) & $\begin{array}{c}\text { Grasslands and Pastures } \\
\text { (Tratturo) (\%) }\end{array}$ \\
\hline Roccasicura & 5.38 & 2.05 & 45.93 & 46.64 \\
Pescolanciano & 17.14 & 0.05 & 40.97 & 41.83 \\
Duronia & 11.23 & 2.32 & 40.23 & 46.22 \\
Campobasso & 12.56 & 47.44 & 7.89 & 32.11 \\
Campodipietra & 13.75 & 48.79 & 6.44 & 31.02 \\
Pietracatella & 3.49 & 23.10 & 45.76 & 27.65 \\
Gambatesa & 5.55 & 19.63 & 38.80 & 36.02 \\
\hline
\end{tabular}

\section{Discussion}

At present, the routes of organized transhumance are often difficult to identify due to the lack of methodological approaches.

The work presented in this paper, although restricted to a local case, may be considered as a pilot study to assess the use of a combined methodological approach that can be applied at a wider scale in the Mediterranean basin but also in other countries with similar features.

Through the use of historic cartography and aerial images, it was possible to analyze the land use changes and conservation state of one of the most important transhumance routes in central Italy. Because of its linear shape, the tratturo represents a limited element on a regional scale, so its identification can be particularly difficult and can only happen through the support of specific maps and very detailed ancillary information (i.e., archive documents).

Although the interval that we consider is broad and the maps that we used are characterized by different resolutions, it was possible to verify the transformation of drove roads since the 15th century. Moreover, the methodology that we applied allowed us to achieve a 'virtual reinstatement' of Tratturo Castel di Sangro-Lucera in the Molise Region updated in 2014.

An important result of this methodological approach was the identification of Tratturo Castel di Sangro-Lucera's boundaries with the same detailed characteristics of a cadastral parcel, when Land Registry maps do not report information about the tratturo's property. Indeed, it allowed us to draw limits on a scale of 1:2000. At the same time, we were effective in correcting occasional mistakes present in Bonamici's Reinstatement, rendering the limits updated to 1883, when the tratturo was actually a path of about $111 \mathrm{~m}$ in width.

Despite a real decrease in the width and total surface of the Tratturo Castel di Sangro-Lucera, due to the numerous incidents of squatting included in the agricultural land cover class, the tratturo is an important landscape element still recognizable in some municipalities. The principal dynamic of squatting was described by using toponyms. In particular, the toponyms Tratturo-Drove road, Taverna-Tavern, Difesa/Defenza/Iazzo—fenced pasture, Salera—a place for shepherd salt distribution, Casone - temporary housing, Pagliaro/Pagliaio—hut, Termine - milestones highly related to drove roads were used. Furthermore, these toponyms provide information about the interactions between man and his environment and temporal dynamics. Most of the tangible elements correlated to transhumance (taverns, milestones, etc.) are currently in a state of abandonment, but they are still perceptible thanks to their physical traces and the toponyms reported on maps.

In a more general context, this methodological approach can be used to describe the dynamics of land use, comparing historical and recent maps with the support of archive documentation. We propose that the methodology presented here can be applied not only to the entire network of drove roads in southern Italy, but also to other Mediterranean countries with transhumance heritage. 
For example, the Spanish National Geographic Information Center Portal (http:/ /www.ign. es/web/ign/portal/inicio) can provide a large number of topographic and historical aerial photos reporting drove road boundaries [4,52-54]. Similar archive sources can provide information on the modification of the status of public land cañadas [34,55]. A screenshot of the Spanish National Geographic Information Center Portal is given in Figure S1 of the Supplementary Materials, while Table S1 describes the cartographic documentation available.

The historical cartography approach presented here can also be applied to the case study of Grand Draye des Tropeaux in France (Cevennes) using maps (years 1820-1866) and recent orthophotos available on https://www.geoportail.gouv.fr. A screenshot of the French cartographic portal is given in Figure S2 of the Supplementary Materials, while Table S2 describes the cartographic documentation available.

In a global context, we propose that our methodological approach can be applied on the Australian stock route network, linked with European and Australian historical cartography [56].

Furthermore, our work may provide useful suggestions for the management of drove roads towards the valorization of touristic potential. Indeed, cartographic information could be implemented in a web-GIS-based guide that integrates actual and ancient maps and georefenced photos (point of interest) of material and immaterial features such as milestones, stone walls, ancient pictures of transhumant people, and local dairy products [57].

The availability of European states and regional archives' [58,59] ancient or derived maps [60] of drove roads could implement a governance of an European network, as described in the Australian case, which can represent an important step in analyzing the transhumance routes' history their management, the changing landscape, and their potential in effective pan-European touristic and ecological corridors features.

\section{Conclusions}

The results obtained in this pilot study, although they refer to a local case, provide a methodological approach that can be applied to transhumance heritage analysis in countries where ancient maps are available. A further development of this work will involve more extensive analysis using wider land cover data, enlarging the study area beyond the tratturo boundaries.

With regard to drove road management issues, our data can suggest some indications on routes restoration, valorization, and conservation. In areas where it is difficult to identify the boundaries of drove road for the presence of a homogeneous landscape matrix (e.g., pasture areas), plantations of autochthonous shrubs and trees might be useful to identify the linear features of a drove road, whereas thematic informational signs with ancient maps and historical features along the boundaries, together with information and communication technology (ICT) applications, may represent a useful tool for self-guided tours for tourists.

Supplementary Materials: The following are available online at www.mdpi.com/2073-445X/7/1/3/s1. Figure S1: Spanish National Geographic Information Center. It is possible to download from the cartographic portal http:/ /www.ign.es/web/ign/portal/inicio several maps, which report the drove roads' boundaries and frequently the land use. Some of these maps are: IGYE's maps with a scale 1:25,000 of 1900, IGN's maps with a scale 1:50,000 previous the Second World War and more recent maps with various scales drawn up between 1985 and 2014. Moreover, it is also possible to download aerial photograms and orthophotos realized between 1970 and 2014; Table S1: Detail of cartographic documentation described in Figure S1; Figure S2. French cartographic portal https:/ / www.geoportail.gouv.fr. It is possible to consult several maps, where the draylles are drawn up. Some of these maps are: Carte d'État-Major (scale 1:40,000) drawn up between 1820 and 1866, Cartographic maps of 1950 (scale 1:25,000) and recent vectorial maps drawn in 2017. It is also possible to consult aerial photograms and orthophotos realized between 1950 and 2014. Moreover, the maps can be consulted thanks to the WMS service of the National Institute of Geographic and Forest Information (IGN); Table S2: Detail of cartographic documentation described in Figure S2.

Acknowledgments: We are very grateful to the Isernia Land Registry Office for support during the acquisition of information about the cadastral parcels. We also thank Marco Ottaviano, University of Molise, for supporting cartography validation. We also wish to thank Molise Explorer and Attraverso il Molise Association for the planning support. 
Author Contributions: Michele Minotti and Paolo Di Martino defined the research design; Michele Minotti performed the data collection, map calibration, and land use mapping; Carmen Giancola carried out the vegetation analysis; Michele Minotti, Piera Di Marzio, Carmen Giancola, and Paolo Di Martino wrote the paper.

Conflicts of Interest: The authors declare no conflict of interest.

\section{Appendix A}

\section{A.1. Data Source Details}

\section{A.1.1. Capecelatro's Atlas}

This is a collection of 29 reinstatements, commissioned in 1649 and completed in 1652 . It took its name from the customs governor Ettore Capecelatro, Marchese di Torello (Marquis of Torello). The atlas comprises 552 pages and represents the first document containing depictions of the drove roads (Figure A1). The atlas was made of parchment paper and iron gall ink was used. The reports of reinstatement contain valuable information on the state of the drove road network and any illegal uses of tratturo territory, while also mentioning the occupiers. The reinstatement of the Tratturo Castel di Sangro-Lucera (Archivio di Stato di Foggia, Dogana delle pecore di Puglia, s. I, 18) was acquired from the Archivio di Stato di Foggia (State Archive of Foggia) in digital format. It consists of a report of about 50 pages, which also includes 16 maps drawn by Giuseppe De Falco. Every map measures $42 \times 34$ $\mathrm{cm}$; toponyms are reported, and, in a simplified way, the towns, taverns, isolated houses, churches, rivers, bridges, the presence of trees in grazing lands, orographic reliefs, and roads are represented. The tratturo has been primarily drawn in linear form through a non-planimetric representation; the agrimensori included in every map the distance in Neapolitan feet between the milestones and other relevant elements (such as taverns). This numerical information has been essential in rigorously describing the state of the tratturo.

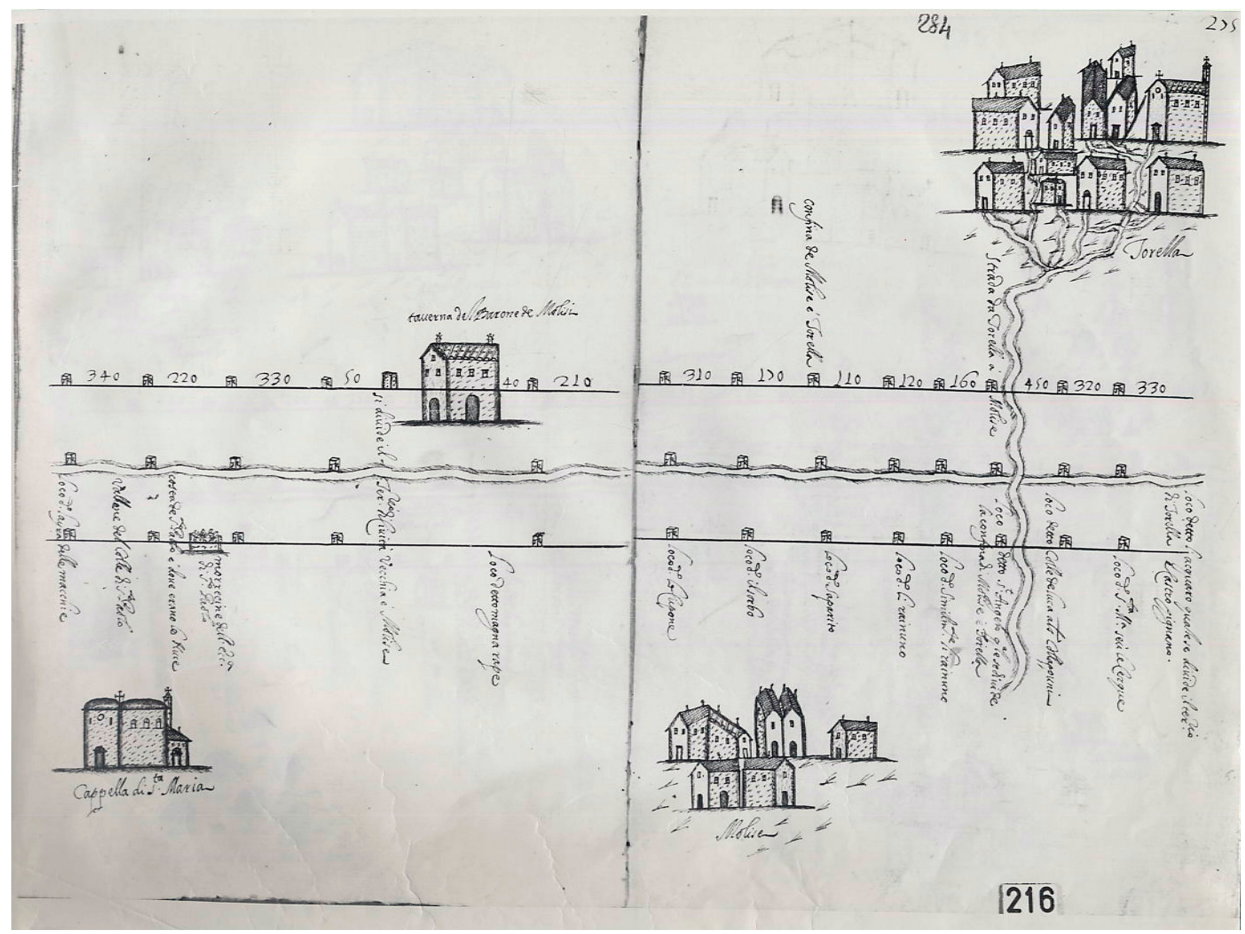

Figure A1. Details of Capecelatro's Atlas, Sheet 284. In the map, in addition to the tavern, it is possible to recognize the milestones with related distances in Neapolitan feet. Authorization to publish $\mathrm{n}$. 5/2016, prot. 2915/28.34.01.10 of 2016.10.14, granted by the Director of Archivio di Stato di Foggia. 


\section{A.1.2. Map of Southern Italy (ITMI)}

After the unification of Italy, the Istituto Topografico Militare Italiano (Italian Topographic Military Institute) quickly produced (1860-1875) an Carta dell'Italia Meridionale (Official map of southern Italy) with a scale of 1:50,000 [61]. To identify the Tratturo Castel di Sangro-Lucera we used five sheets (with dimensions of about $50 \times 70$ ) published in 1875. Although this is small-scale cartography, the maps are sufficiently detailed and are faithful to the reality of the land features, including the drove roads' network (Figure A2). We used another nine quadrants to identify the Tratturo Pescasseroli-Candela and Tratturo Celano-Foggia; because of the scale of the map, the toponymy is not detailed. These cartographies were digitized and subsequently georeferenced.

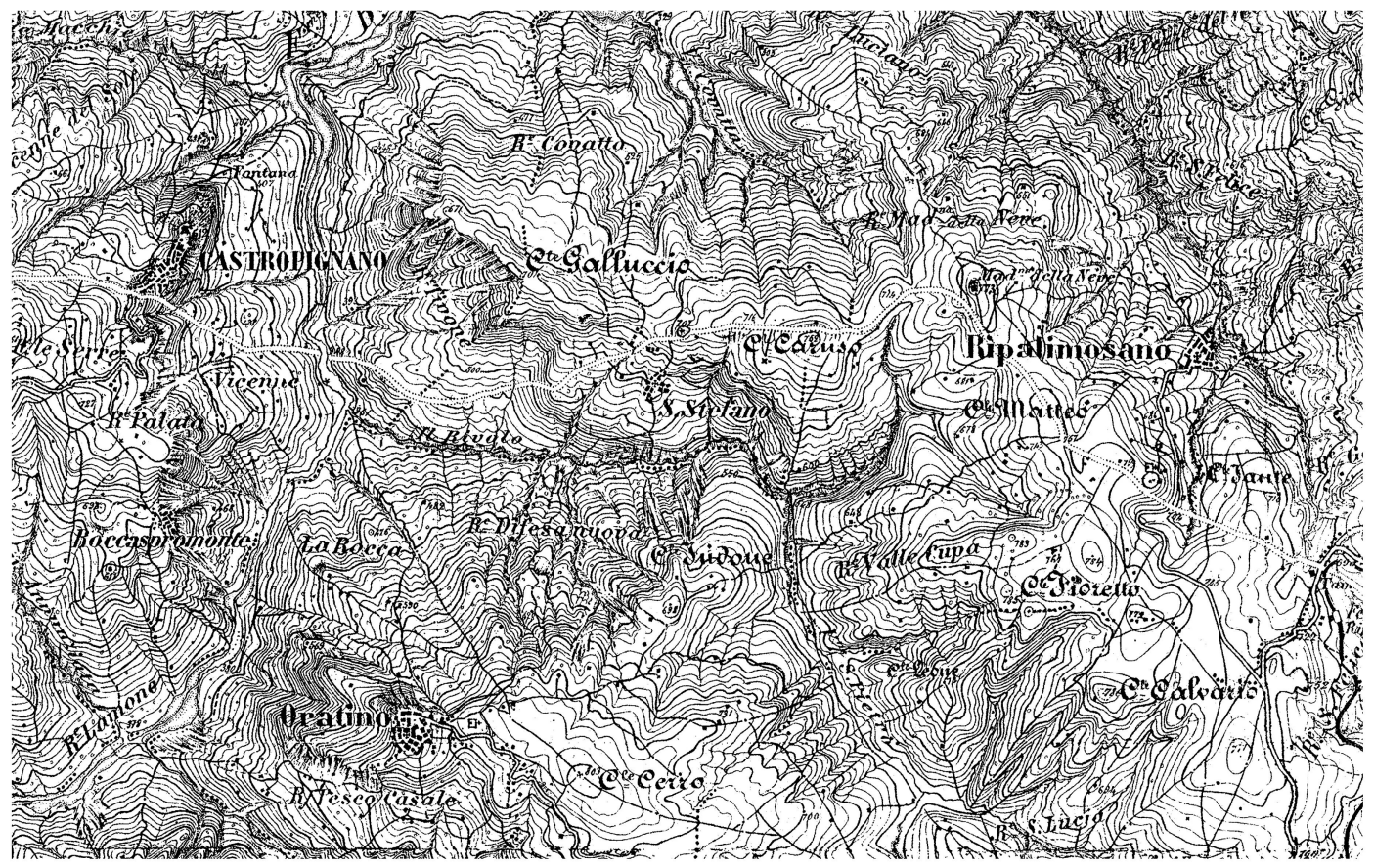

Figure A2. Details of sheet 1:50,000, it is possible to recognize the tratturo's boundaries represented by two dotted lines. In particular, it can be noticeable above the toponym C. Caruso. The tratturo's width is not drawn with the same scale of the map. Authorization to publish n. 6959 of 2017.10.03 granted by Istituto Geografico Militare Italiano (www.igmi.org).

\section{A.1.3. Eduardo Bonamici's Reinstatement (BR)}

Following the rules of 18th March 1881, the Ministry of Finance ordered that this reinstatement would be the last one [40]. The reinstatement, which was entrusted to the Forest Inspectorate, began in 1875 and ended in 1884. The documentation of this reinstatement provides very detailed and precise information about the status of the tratturo. The reinstatement of the Tratturo Castel di Sangro-Lucera was achieved by Eduardo Bonamici and the surveyor Carlo Ciampi between 1881 and 1883. It contains a short introduction, a concise history of the tratturo, summary tables of distances and angles between the milestones, planimetries, and information about occupations (Figure A3). The documentation is featured in maps with a 1:5000 scale (68 tables), while when the tratturo crossed or was close to towns, maps were drawn on a scale of 1:2000 ( 1 table) and 1:1000 (5 tables). The tables are about $38 \times 47 \mathrm{~cm}$ in size and are collected on single manuscript, produced with paper obtained from mechanical pulping and with the use of India ink. Each map reports on the tratturo divided according to administrative boundaries, reporting the towns, the houses, the rivers, the bridges, the presence of vegetation, roads and the milestones, with the distance between them and the equivalent angles also being reported. Unlike in the reinstatement of the Capecelatro, the maps are characterized by a modern territorial 
representation, although they do not represent any detail of the landscape outside the tratturo and report a lack of toponymy. This reinstatement (Archivio di Stato di Campobasso, reintegra di Bonamici, Tratturo Castel di Sangro-Lucera, volume 2) was acquired in digital format from the Archivio di Stato di Campobasso (State Archives of Campobasso) and the geographical references were created in the GIS environment.

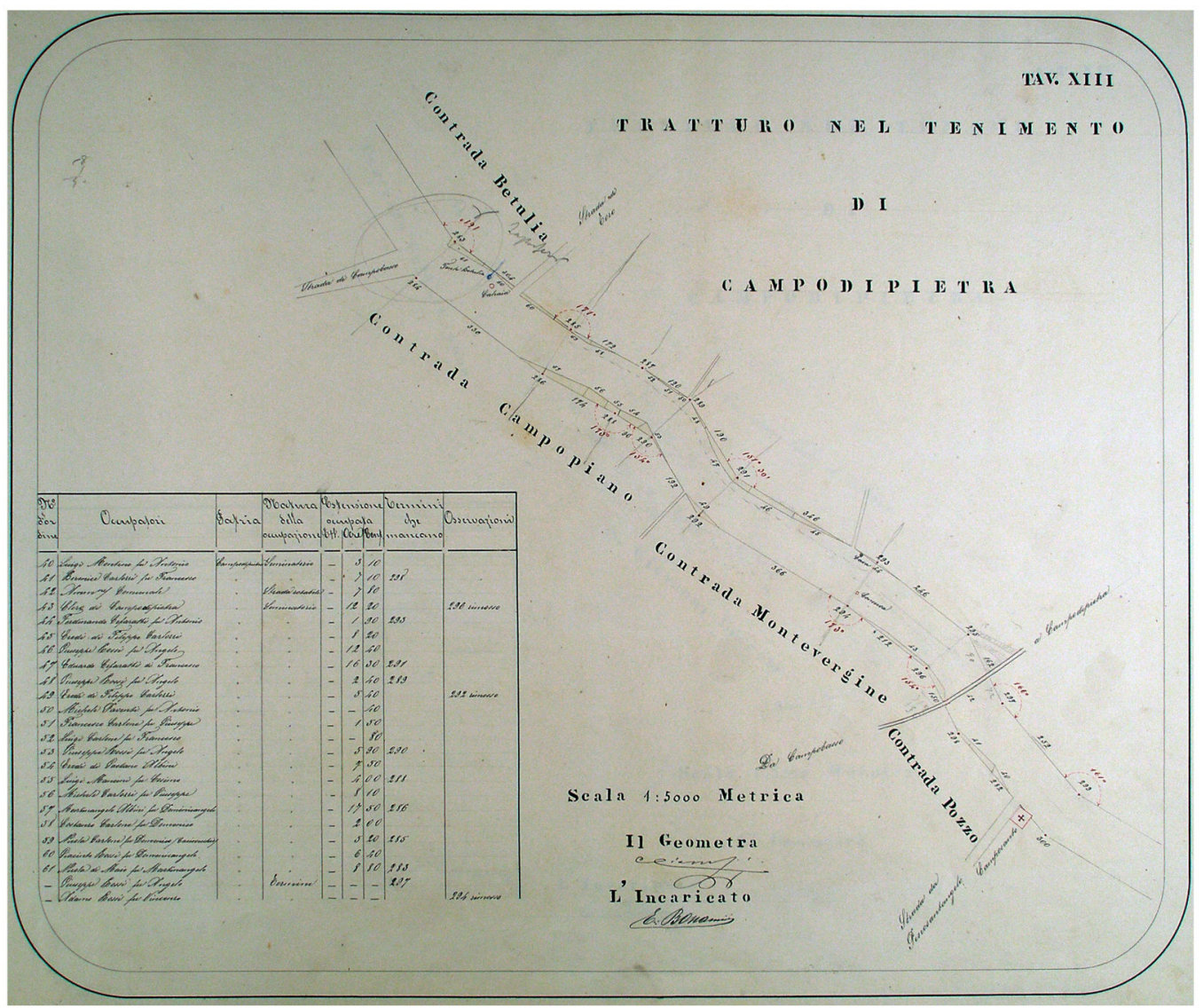

Figure A3. Details of Bonamici's reinstatement, table XIII. The map reports the tratturo's boundaries, the distances in meters among milestones, the angles included between two milestones (red ink) and the presence of squatting (yellow ink). The details of squatting are listed in the table. Authorization to publish n. 0004086/28.28.00/1 of 2016.02.20 granted by the Director of Archivio di Stato di Campobasso.

\section{A.1.4. The GAI Flight (GAI)}

The GAI (Gruppo Aereonautico Italiano - Italian Aeronautic Group) flight, also called Volo Base, is a historical document of great value in terms of geographical information, as it represents the first Italian planimetric and stereoscopic aerial photography. It was produced by the Italian Aeronautical Group under the coordination of the Military Geographical Institute in the context of post-war agreements. The Volo Base was carried out to evaluate the damage caused by the bombing and to verify how much of it has been produced through economic aid from the Marshall Plan [62]. The frames are in black and white and are $23 \times 23 \mathrm{~cm}$ in size, with an average scale for all frames of 1:33,000. A total of 12 frames were produced in 1954 to represent the study area (Frames: 3759, 3781, 3847, 3882, 4078, 4174, 4226, $4267,4487,4537,4573,4637)$. The frames were digitized and then georeferenced.

\section{A.1.5. The Map of Italy (IGMI)}

The origins of this cartography, drawn by the Istituto Geografico Militare Italiano (Italian Geography Military Institute, the name of Istituto Topografico Militare after the 1882), are closely connected to the 
Great Map of Italy (1878-1903) and, in particular, to topographical surveys with a scale of 1:25,000, which allowed the production of maps typified by an extraordinary richness of topographical elements. These maps are called Tavolette (Tablets) and they are $45 \times 50 \mathrm{~cm}$ in size. This cartography was officially adopted as the Italian basic map in 1878. It is characterized by an extreme attention to topography and toponymy, in addition to the usual information such as roads and orography, and there is important information related to the type of vegetation, the presence of drystone walls, ruins, and last but not least the location of drove roads (Figure A4). To identify the Tratturo Castel di Sangro-Lucera, we used nine tablets drawn in 1957.

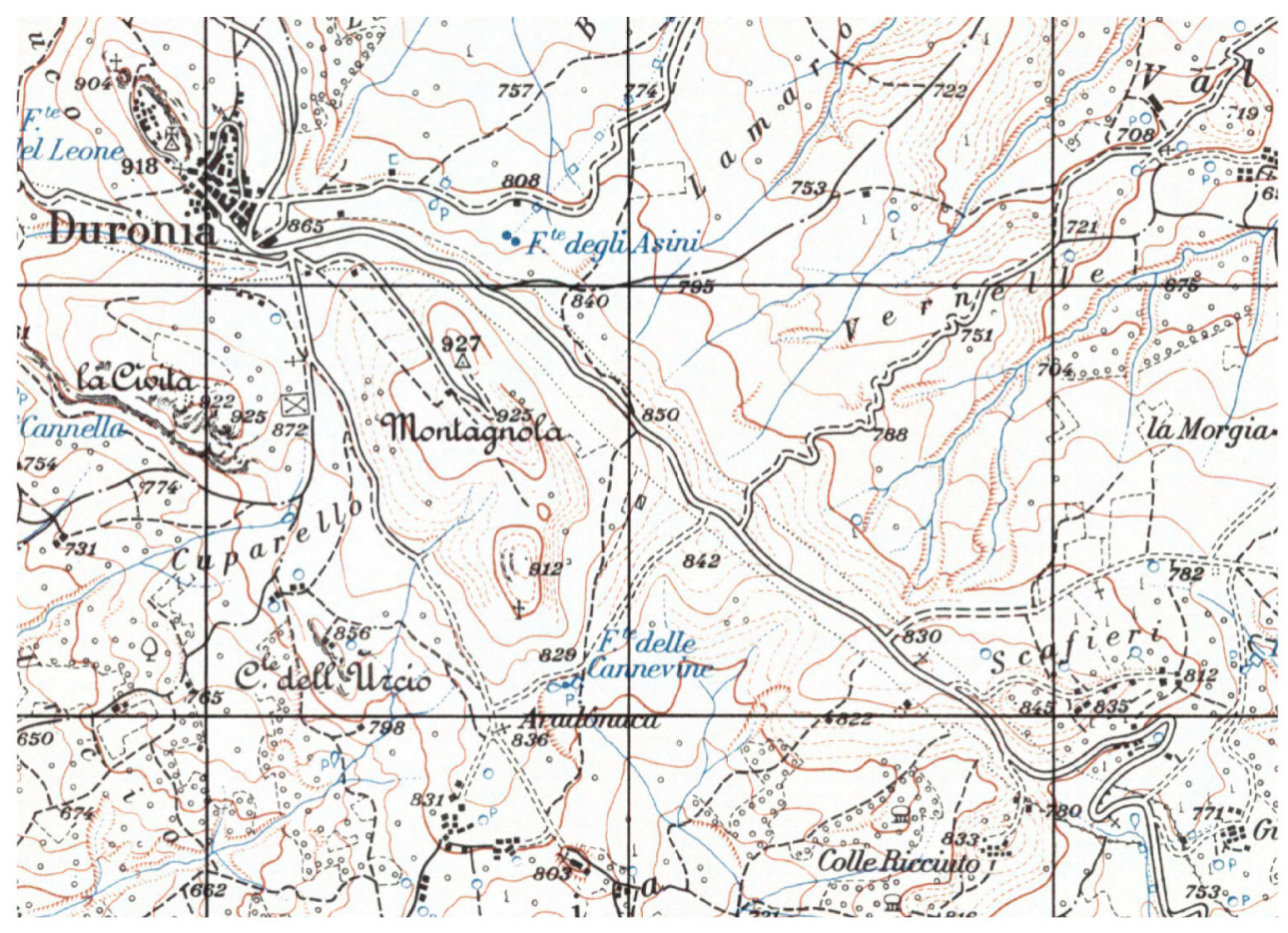

Figure A4. Details of IGM tablets. As reported in Figure A2, the Tratturo Castel di Sangro-Lucera is represented with two dotted lines. It is possible to notice its narrowing nearby the residential area of Duronia and the presence of an ordinary road, nowadays named Provincial Street 46 . Authorization to publish n. 6959 of 2017.10.03 granted by Istituto Geografico Militare Italiano (www.igmi.org).

\section{A.1.6. The Land Registry (1947-2005)}

This is a geometrical parcel cadastre, but is not probative since it does not certify real rights on real estate. In our case the consistency of the tratturo was verified, as a state property, through the Land Registry information, by consulting hundreds of cadastral certificates. The cadastre of land conducts a census of land parcels (minimum unit), which are drawn on the Land Registry maps, otherwise a complete mapping of the area is drawn on a scale 1:2000, in which the toponymy is not detailed. Through the Web Map Service (WMS) of the Molise Region [63] the Land Registry maps were displayed on GIS software to draw the limits of the tratturo (Figure A5). 


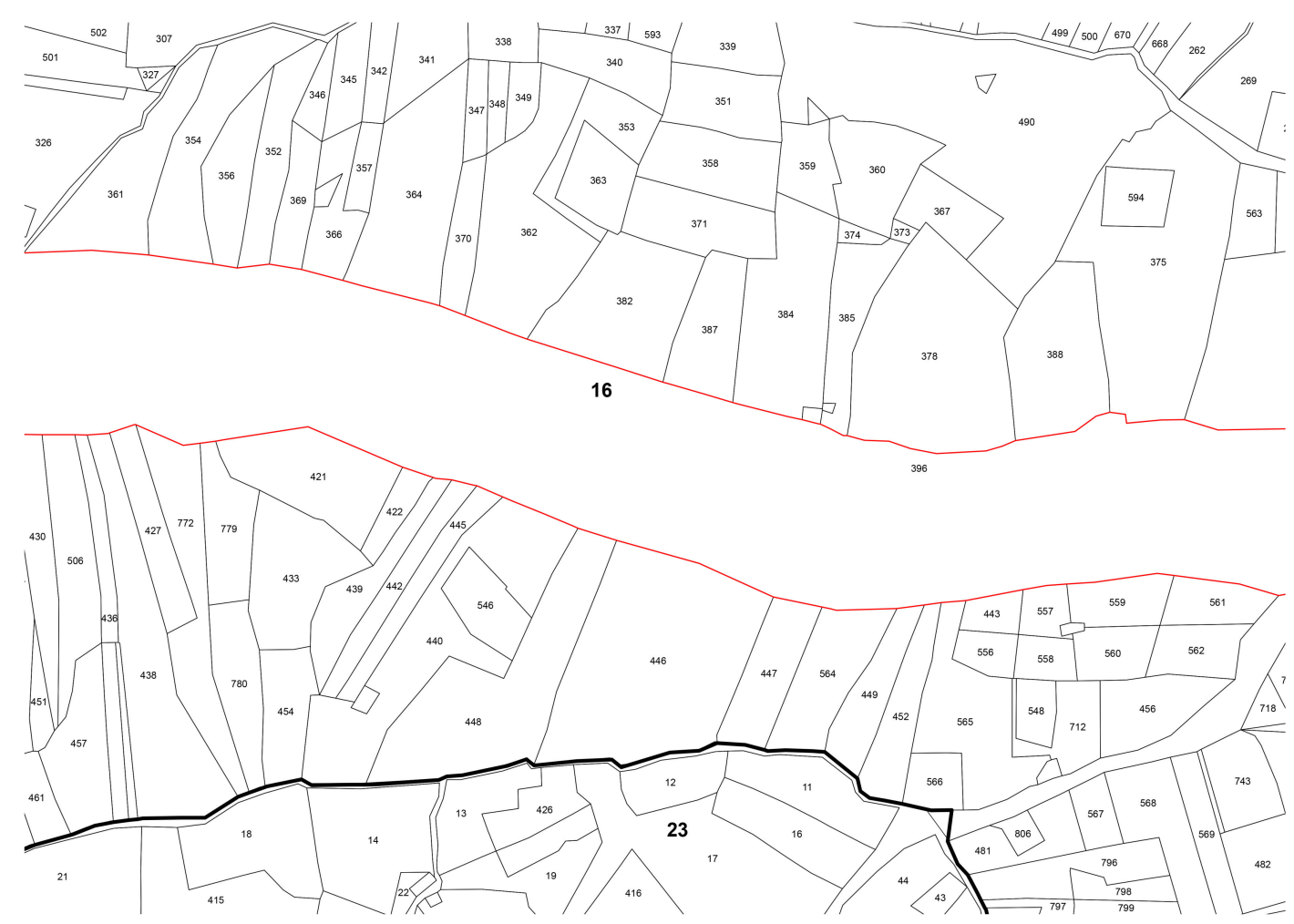

Figure A5. Details of land registry maps. The tratturo is represented with a red line and usually it is identified as a unique linear parcel with variable size; in the figure the tratturo is the parcel number 396 in sheet number 16.

\section{A.1.7. The Aerial Images (2012-2014)}

Using GIS software, through the 'Basemap' service, color aerial images from DigitalGlobe were displayed. These images have a resolution of $60 \mathrm{~cm}$ (Source: Esri, DigitalGlobe, GeoEye, Earthstar Geographics, CNES/Airbus DS, USDA, USGS, AEX, Getmapping, Aerogrid, IGN, IGP, swisstopo, and the GIS User Community).

\section{References}

1. Bower, J. The Pastoral Neolithic of East Africa. J. World Prehist. 1991, 5, 49-82. [CrossRef]

2. Dong, S.; Kassam, K.-A.S.; Tourrand, J.F.; Boone, R.B. (Eds.) Building Resilience of Human-Natural Systems of Pastoralism in the Developing World: Interdisciplinary Perspectives; Springer International Publishing: Cham, Switzerland, 2016. [CrossRef]

3. Gómez-Ibáñez, D.A. Energy, economics, and the decline of transhumance. Geogr. Rev. 1977, 67, 284-298. Available online: http:/ / www.jstor.org/stable/213723 (accessed on 11 November 2016). [CrossRef]

4. Morgado, P.; Rocha, L. Caminhos antigos do Concelho de Monforte. Sci. Antiquitatis 2017, 1, 287-308. Available online: http:/ /www.scientiaantiquitatis.uevora.pt/index.php/SA/article/view/93 (accessed on 15 December 2017).

5. Bunce, R.G.H.; Pérez-Soba, M.; Jongman, R.H.G.; Gómez Sal, A.; Herzog, F.; Austad, I. Transhumance and Biodiversity in European Mountains; Report of the EU-FP5 Project TRANSHUMOUNT (EVK2-CT-2002-80017); IALE Publication Series; IALE Publication: Wageningen, The Netherlands, 2004.

6. Oteros-Rozas, E.; Gonzalez, J.A.; Martìn-Lòpez, B.; Lòpez, C.A.; Zorrilla-Miras, P.; Montes, C. Evaluating ecosystem services in transhumance cultural landscapes: An interdisciplinary and participatory framework. GAIA Ecol. Perspect. Sci. Soc. 2012, 21, 185-193. 
7. Papachristou, T.G. Greece's grazing/forage resources for livestock production. In Ecosystem Services and Socio-Economic Benefits of Mediterranean Grasslands, Option Méditerranéennes 114; Kyriazopoulos, A., López-Francos, A., Porqueddu, C., Sklavou, P., Eds.; CHIEAM: Zaragoza, Spain, 2016; pp. $29-42$.

8. Francioni, M.; Toderi, M.; Lai, R.; Trozzo, L.; Foresi, L.; Sciarra, F.; Avanzolini, P.; Sedić, E.; Budimir, K.; Santilocchi, R.; D'Ottavio, P. Does transhumant sheep system provide ecosystem services for climate change adaptation in Mediterranean environment? In Ecosystem Services and Socio-economic Benefits of Mediterranean Grasslands, Option Méditerranéennes 114; Kyriazopoulos, A., López-Francos, A., Porqueddu, C., Sklavou, P., Eds.; CHIEAM: Zaragoza, Spain, 2016; pp. 103-106.

9. Bunce, R.G.H.; De Aranzabal, I.; Schmitz, M.F.; Pineda, F.D. A Review of the Role of Drove Roads (Cañadas) as Ecological Corridors; Alterra-Rapport 1428; Alterra: Wageningen, The Netherlands, 2006.

10. Manzano-Baena, P.; Casas, R. Past, present and future of transhumance in Spain: Nomadism in a developed country. Pastoralism 2010, 1, 172-190. [CrossRef]

11. Biber, J.P. Transhumance in France. Pastoralism 2010, 1, 91-98. [CrossRef]

12. Luick, R. Transhumance in Germany.Report to European Forum on Nature Conservation and Pastoralism; European Forum on Nature Conservation and Pastoralism (EFNCP) and University of Applied Sciences Rottenburg/Fachhochschule Rottengurg, Schadenweilerhof: Rottenburg, Germany, 2008. Available online: http:/ / www.efncp.org/download/Swabian_Alb_F_F_Download.pdf (accessed on 15 November 2016).

13. Huband, S.; McCracken, D.I.; Mertens, A. Long and short-distance transhumant pastoralism in Romania: Past and present drivers of change. Pastoralism 2010, 1, 55-71. [CrossRef]

14. Matley, I.M. Transhumance in Bosnia and Herzegovina. Geogr. Rev. 1968, 58, 231-261. [CrossRef]

15. Hadjigeorgiou, I. Past, present and future of pastoralism in Greece. Pastor. Res. Policy Pract. $2011,1$. [CrossRef]

16. Peattie, R. M. Mountain Geography-A Critique and Field Study; Harvard University Press: Cambridge, MA, USA, 1936.

17. Graziani, M.; Avram, M. Il "genius loci" del "tratturo". Recupero del retaggio della transumanza nel Parco Nazionale d'Abruzzo, Lazio e Molise (Italia). ETNICEX Revista de Estudios Etnograficos 2011, 2, 77-92.

18. Takola, E.; Sidiropoulou, A.; Karatassiou, M. The impact of transhumance abandonment on land use changes in Mount Pindos (Greece). In Ecosystem Services and Socio-Economic Benefits of Mediterranean Grasslands, Option Méditerranéennes 114; Kyriazopoulos, A., López-Francos, A., Porqueddu, C., Sklavou, P., Eds.; CHIEAM: Zaragoza, Spain, 2016; pp. 143-146.

19. United Nations Educational, Scientific and Cultural Organization (UNESCO); World Heritage Centre. The Causses and the Cévennes, Mediterranean Agro-Pastoral Cultural Landscape 2011. Available online: http:/ / whc.unesco.org/en/list/1153 (accessed on 2 October 2017).

20. United Nations Educational, Scientific and Cultural Organization (UNESCO); World Heritage Centre. Hallstatt-Dachstein/Salzkammergut Cultural Landscape 1997. Available online: http:/ / whc.unesco.org/ en/list/806 (accessed on 2 October 2017).

21. United Nations Educational, Scientific and Cultural Organization (UNESCO); World Heritage Centre. PyrénéesMont Perdu 1997. Available online: http:/ / whc.unesco.org/en/list/773 (accessed on 2 October 2017).

22. United Nations Educational, Scientific and Cultural Organization (UNESCO); World Heritage Centre. The Transhumance: The Royal Shepherd's Track-Tentative list01/06/2006. Available online: http://whc. unesco.org/en/tentativelists/5005/ (accessed on 5 August 2016).

23. United Nations Educational, Scientific and Cultural Organization (UNESCO); World Heritage Centre. Mesta Livestock Trails-Tentative list24/07/2007. Available online: http:/ / whc.unesco.org/en/tentativelists/5128/ (accessed on 6 October 2017).

24. Ministerio de Educación, Cultura y Deporte. Real Decreto 385/2017, de 8 de Abril, por el que se Declara la Trashumanciacomo Manifestación Representativa del Patrimonio Cultural Inmaterial. Available online: https:/ / www.boe.es/diario_boe/txt.php?id=BOE-A-2017-4009 (accessed on 2 October 2017).

25. Pellicano, A.; Zarrilli, L. I toponimi della transumanza nell'Abruzzo aquilano tra retaggio storico e persistenze socio-culturali. In Toponomastica Italiana. L'eredità Storica e le Nuove Tendenze; Società Geografica Italiana: Rome, Italy, 2008; pp. 213-231.

26. Bil, A. Transhumance place-names in Perthshire. Soc. Antiq. Scotl. 1992, 122, 383-402.

27. Landi, F.; Calzolai, L. Transhumance routes in Tuscany: Cartography, place names, virtual landscaping. Rev. Hist. Geogr. Toponomast. 2015, 10, 99-124. 
28. Mallorquí, E.; Amigó, R.; Rabella, J.A.; Tort, J.; Roma, F. Toponímia, Paisatge i Cultura: Els Noms de lloc de la Lingüística, la Geografia y la Història; Documenta Universitaria Biblioteca D’història Rural: Girona, Spain, 2015.

29. Agnoletti, M. Paesaggi Rurali Storici: Per un Catalogo Nazionale; Laterza: Bari, Italy, 2011; pp. 420-422.

30. Ley 3/1995, de 23 de Marzo. Agencia Estatal Boletín Oficial del Estado n. 71 de 24 marzo de 1995. Available online: https: / / www.boe.es/buscar/doc.php?id=BOE-A-1995-7241 (accessed on 20 October 2017).

31. Ministerio de Agricultura, Alimentación y Medio Ambiente. Cuadernos de la Trashumancia, Vías Pecuarias. Available online: http:/ / www.mapama.gob.es/es/desarrollo-rural/temas/politica-forestal/vias-pecuarias/ rvp_cuadernos_trashumancia.aspx (accessed on 22 december 2017).

32. Cameron, J.M.R.; Spooner, P.G. Origins of Travelling Stock Routes. 2. Early development, management, and the growing embrace of the law (1830-70s). Rangel. J. 2010, 32, 341-351.

33. Spooner, P.G.; Firman, M. Yalmambirra Origins of Travelling Stock Routes. 1. Connections to Indigenous traditional pathways. Rangel. J. 2010, 32, 329-339. [CrossRef]

34. Garcia Martí, P. La Mesta: Transumanza e Istituzioni in Castiglia dal XIII al XIX Secolo; Mediterranea Collana di Studi Storici 12; Edipuglia: Bari, Italy, 1998.

35. Guenzi, A.; Rossi, R. Institutions, natural resources and economic growth in the modern age: The case of Dogana delle Pecore in the Kingdom of Naples (XV-XVIII Centuries). Rev. Econ. Inst. 2014, 5. [CrossRef]

36. Grana, S. Istituzioni Delle Leggi Della Regia Dohana di Foggia; Stamperia Raimondi: Napoli, Italy, 1770.

37. Russo, S. Il conflitto tra agricoltura e pastorizia transumante nella Dogana di Foggia in età moderna. Mélanges de l'École Française de Rome-Antiquité 2016, 128-132. Available online: http:/ / mefra.revues.org/3451 (accessed on 7 October 2017).

38. Marino, J.A. Le Economie Pastorali nel Regno di Napoli; Guida Editori: Napoli, Italy, 1992.

39. Pelicano, A. Geografia e Storia dei Tratturi del Mezzogiorno: Ipotesi di Recupero Funzionale di una Risorsa Antica; Aracne: Roma, Italy, 2007.

40. Di Cicco, P. La Cartografia Tratturale. In La Capitanata Rassegna di Vita e di Studi della Provincia di Foggia; Archivio di Stato di Foggia: Foggia, Italy, 1987; p. II. Available online: http:/ / www.bibliotecaprovinciale. foggia.it/capitanata/1987/1987pdf_parte2/1987_pII_51-57_diCicco.pdf (accessed on 9 September 2016).

41. Caliandro, L.P.; Loisi, R.V.; Dal Sasso, P. Historical road system and farmhouses in Apulia. J. Agric. Eng. 2013, 44, 441-447. [CrossRef]

42. Molise Regional Law n. 9 of 11 April 1997 "Tutela, Valorizzazione e Gestione del Demanio Tratturi". Bollettino Ufficiale $n^{\circ} 08$ del 16/04/97; Regione Molise: Campobasso, Italy, 1997.

43. Molise Regional Committee Resolution No. 633 of 29 November 2013. Available online: http://www2. regione.molise.it/web/grm/deliberegiuntaanni2010.nsf/0/0E92C364704D9EDEC1257C45003E30EF? OpenDocument (accessed on 15 September 2016).

44. Attraverso il Molise, sui Regi Tratturi d'Italia. Available online: http://www.tratturocoast2coast.org/ (accessed on 26 May 2016).

45. Meini, M.; Adducchio, D.; Ciliberti, D.; Di Felice, G. Landscape conservation and valorization by satellite imagery and historic maps: The case of Italian transhumance routes. Eur. J. Remote Sens. 2014, 47, 375-387. [CrossRef]

46. Petrocelli, E. Itinerari Sulle vie Della Transumanza; Touring Editore: Milano, Italy, 2011; pp. 149-153.

47. Liebetanz, G. Camminandosi, Tratturo Tratturo: Indagine Topografica Comparata sul Territorio del Tratturo Lucera-Casteldisangro al Seguito di un Gregge Virtuale Seguendo il filo d'Arianna dell'Atlante Capecelatro; IRESMO: Campobasso, Italy, 1999.

48. European Environment Agency. CORINE Land Cover. Available online: https://www.eea.europa.eu/ publications/COR0-landcover (accessed on 11 April 2016).

49. Snedecor, G.W.; Cochran, W.G. Statistical Methods, 7th ed.; Iowa State Univ. Press: Ames, IA, USA, 1980.

50. Cohen, J. A coefficient of agreement for nominal scales. Educ. Psychol. Meas. 1960, 20, 37-46. [CrossRef]

51. De Martino, D. Lavoro Istorico Positivo sul Tavoliere di Puglia; Tipografia Simoniana: Napoli, Italy, 1857.

52. Ortega Cruz, D.J.C. Deslinde de la Vía Pecuaria “Cañada Real Galiana o Cordel Segoviano” en el Tramo Comprendido Dentro del Término Municipal de Pulgar Incluida la Parte Caballera con Cuerva, en la Provincia de TOLEDO. Master's Thesis, Universidad de Valladolid, Seville, Spain, 2014.

53. Mangas Navas, J.M. Determinación y Recuperación de la red Nacional de vías Pecuarias. In Proceedings of the I Congreso Nacional de Vías Pecuarias, Madrid, Spain, 4-7 May 2005; pp. 169-174. 
54. Ortiz Borrego, I. Directrices, objetivos, instrumentalización y datos generales del plan de recuperación y ordenación de las vías pecuarias de la Comunidad autónoma de Andalucía. In Proceedings of the I Congreso Nacional de Vías Pecuarias, Madrid, Spain, 4-7 May 2005; pp. 237-244.

55. Barriguete, F.M. Archivo de la Mesta: Tipologías documentales y posibilidades de investigación (XVI-XVIII). Cuadernos de Historia Moderna 1996, 17, 193-216.

56. Lentini, P.E.; Fischer, J.; Gibbons, P.; Lindenmayer, D.B.; Martin, T.G. Australia's Stock Route Network: 1. A review of its values and implications for future management. Ecol. Manag. Restor. 2011, 12, 119-127. [CrossRef]

57. Ntassiou, K.; Doukas, I.D.; Papadopoulos, I. On the study, modernisation, support and promotion of transhumance, through a dedicated web-GIS. IJSAMI 2016, 2, 193-205. [CrossRef]

58. National Library of Australia. Map of New South Wales Showing Stock Routes, Tanks, Wells, and Trucking Stations, 1888. Available online: https:/ / nla.gov.au/nla.obj-232204514/view (accessed on 20 December 2017).

59. Plan of Stock Route Hughenden to Cloncurry, Queensland, 1899. Available online: https://nla.gov.au/nla. obj-231770786/view (accessed on 20 December 2017).

60. Ministerio de Agricultura y Pesca, Alimentación y Medio Ambiente. Información Cartográfica de las vías Pecuarias por Provincias. Available online: http:/ / www.mapama.gob.es/es/desarrollo-rural/temas/ politica-forestal/vias-pecuarias/rvp_descargas.aspx (accessed on 22 December 2017).

61. Cantile, A. Lineamenti di Storia Della Cartografia Italiana. Volume Secondo: Dal Seicento al Novecento; GEOWEB: Rome, Italy, 2013.

62. Planetek Italia S.r.l. L'ortorettifica di Fotogrammi Storici Privi di Certificati di Calibrazione con ERDAS LPS: Il volo GAI. Available online: http:/ / www.planetek.it/sites/default/files/LPS_voloGAI_casehistory_ IUAV_Bologna_0.pdf (accessed on 5 May 2016).

63. Portale Cartografico Regionale. Available online: http://servizi.geo.regione.molise.it/arcgis/services/ Catasto/MapServer/WMSServer (accessed on 11 April 2016).

(C) 2018 by the authors. Licensee MDPI, Basel, Switzerland. This article is an open access article distributed under the terms and conditions of the Creative Commons Attribution (CC BY) license (http:/ / creativecommons.org/licenses/by/4.0/). 